\title{
Groundwater-Surface Water Relations in the Fox River Watershed: Insights from Exploratory Studies in Illinois and Wisconsin
}

\section{Relation to National Assessments of Groundwater Availability and Regional Needs}

The WaterSMART initiative of the U.S. Department of the Interior and the Groundwater Resources Program of the U.S. Geological Survey (USGS) are designed to provide information and analysis to stakeholders and decision makers for characterizing our Nation's groundwater and surface water resources to ensure their wise use and future availability for agricultural, municipal, industrial, and environmental needs. In consideration of these objectives and because groundwater and surface water are a single resource, the studies described herein explored the possible effects of shallow groundwater withdrawals on the Fox River. This river represents a principal surface water system in the rapidly urbanizing parts of the Chicago region of northeastern Illinois and Milwaukee region of southeastern Wisconsin (fig. 1). With the area's large population (about 11 million (U.S. Census Bureau, 2013)), redistributing centers of commercial and industrial growth, and dwindling options for water supply, the Fox River may become increasingly relied upon as a supply source for public water. The Great Lakes Basin Compact (Great Lakes Commission, 2003) restricts withdrawals from nearby Lake Michigan; other appropriate surface water sources generally are unavailable; and the bedrock Cambrian-Ordovician aquifer underlying the region can not sustain a return to the long-term, high-volume withdrawals of past years because of yield (Visocky and others, 1985; Avery, 2005; Meyer and others, 2009) and water-quality limitations (Gilkeson and others, 1983; Balding, 1991; Kay, 2013).

A previous hydrologic study of the area, which included numerical simulation (modeling) of groundwater and surface water systems (Meyer and others, 2009), indicated that withdrawals from shallow glacial deposits have reduced natural groundwater discharge to streams (diversion) throughout much of the Fox River watershed, and in turn, resulted in declines in base flow. In some subwatersheds, reductions in discharge approaching 45 percent by 2025 (fig. 2) are indicated. For the simulation, consideration of the potential influence of climate and land-use change on natural groundwater discharge was limited to increasing and decreasing groundwater recharge in the scenarios which represent most- and least-resource intensive conditions. Substantial reductions in natural discharge to streams in the watershed, as indicated, and direct capture of surface waters (inducement) by withdrawals of nearby groundwater wells could limit the available supply of water from the Fox River for public use and (or) substantially impact local stream ecologies dependent on specific base-flow requirements.
With much of the Fox River watershed presently (2014) minimally urbanized, its surface-water and groundwater quality is less impacted by human development than other parts of the Chicago and Milwaukee regions. As such, there is an additional interest in more fully characterizing water quality in the watershed for its long-term protection as a reliable source for public supply.

The exploratory studies in the Fox River watershed were completed at sites in Waukesha, Wisconsin, during 2010 and McHenry, Illinois, during 2011-13 (fig. 1). These paired, shortterm studies specifically were intended to

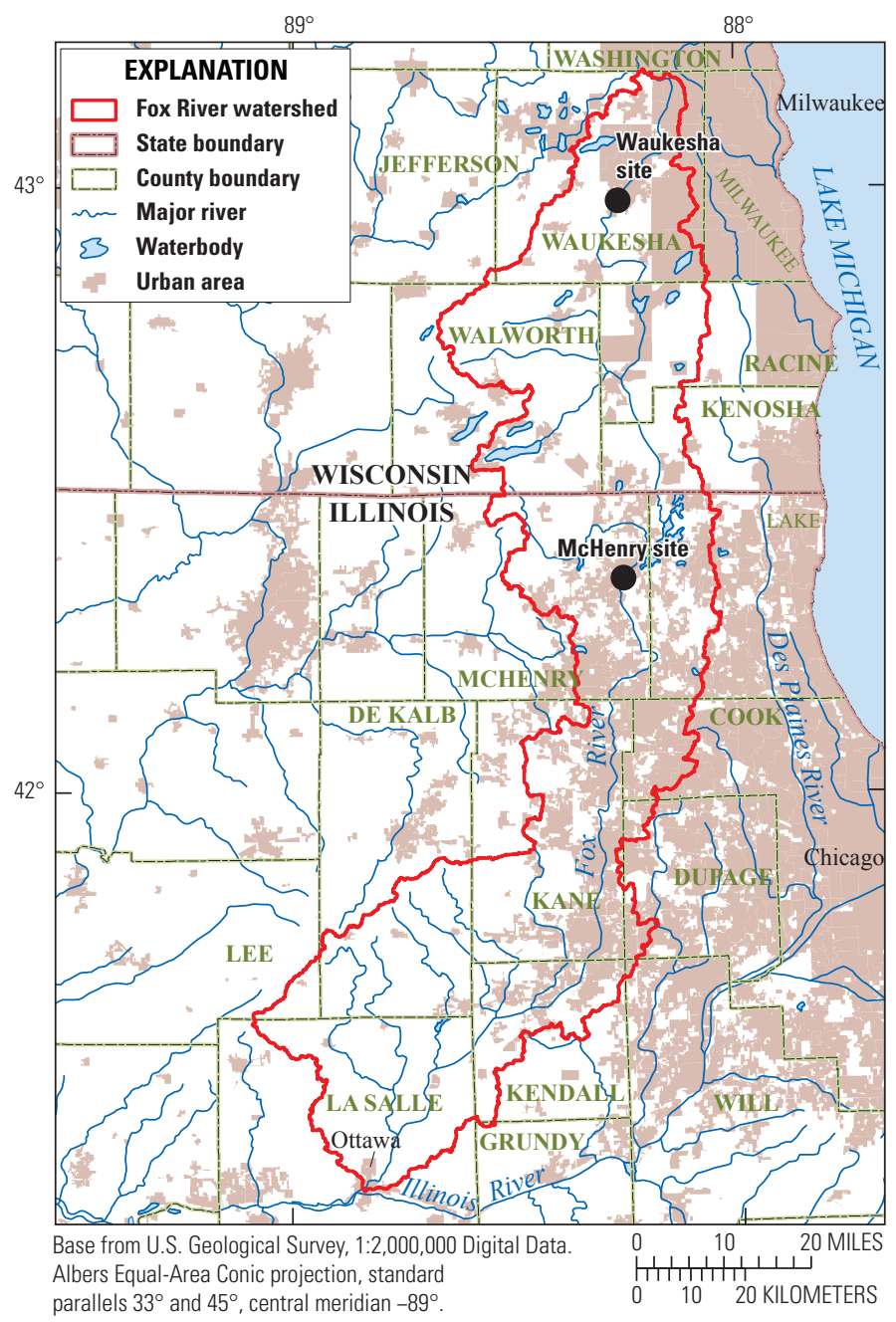

Urban Areas from U.S. Census Bureau, 2009

Figure 1. Fox River watershed and study sites in northeastern Illinois and southeastern Wisconsin. 
Groundwater and surface water, a single resource- "Strong hydraulic connections between the shallow aquifers and surface water reduce drawdown in the aquifer but also tend to reduce groundwater discharge to streams and can reduce streamflow. This reduction is accomplished by diverting groundwater that, under predevelopment conditions, would have discharged to streams, and by inducing flow directly out of surface waters. Thus, the pumping — artificial groundwater discharge - causes a reduction in natural groundwater discharge. This reduction is referred to as streamflow capture.

Streamflow capture is observable as a reduction in base flow. Following a period of transient reduction of heads, most of the water withdrawn by wells is accounted for by reduced base flow, the remainder being accommodated by reduced storage..

Local-scale models permit estimation of the change in natural groundwater discharge to the stream reaches...These estimates approximate the change in natural groundwater discharge to the reaches caused by pumping”

(Meyer and others, 2009, p. 252).

1. assess the potential for high-capacity wells to withdraw some portion of their water from the Fox River or its tributaries,

2. examine various strategies for conducting such assessments, and

3. provide additional characterization of the quality of Fox River system surface waters and groundwaters.

The study sites were selected on the basis of potential for identification and monitoring of directly connected groundwater and surface water systems. The direct measurement and quantification of groundwater fluxes necessary to more fully resolve the extent of induced or diverted streamflow by supply well withdrawals at the study sites was beyond the scope of study of these sites. For this resolution, more in-depth study would be necessary and would be expected to employ and benefit from many of the field techniques described in Rosenberry and LaBaugh (2008) and from numerical simulation of flow (Franke and others, 1998) and water chemistry (Tim Grundl, University of Wisconsin-Milwaukee, written commun., 2013) constrained by available field-study results.

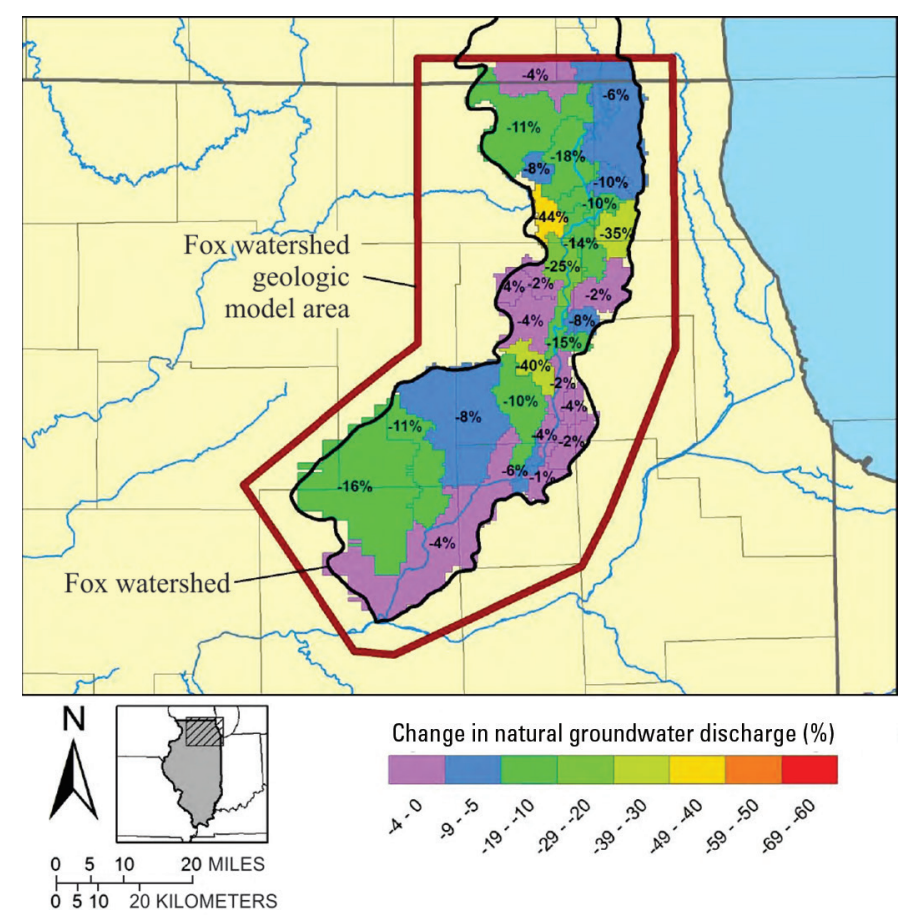

Figure 2. Numerically simulated differences in shallow groundwater discharge resulting from groundwater withdrawals, baseline/current trends scenario, by stream reach, predevelopment to 2025 (Meyer and others, 2012, fig. 73; \%, percent).

\section{Fox River Watershed and Study Sites}

The 202-mi-long Fox River originates near Milwaukee and drains to the Illinois River near Ottawa, Ill. About 60 percent of its reach lies within Illinois (fig. 1). Its watershed encompasses 2,660 $\mathrm{mi}^{2}$ and includes a population of about 1.5 million (U.S. Census Bureau, 2013). Presently, the river is the publicwater source for two cities, Aurora and Elgin, Ill., with a combined withdrawal rate of about $24 \mathrm{Mgal} / \mathrm{d}$ and served population of about 310,000 (Tim Bryant, Illinois State Water Survey, written commun., 2012). The river also is used extensively for boating and fishing.

The Waukesha study site of approximately 4 acres (figs. 1; $3 A$ ) is about 20 mi south of the headwaters of the Fox River. The site was selected for study because (1) two production wells are present within about $96 \mathrm{ft}$ and $235 \mathrm{ft}$, respectively, of the Fox River and a third within about $0.5 \mathrm{mi}$, and (2) wastewater discharges from three upstream treatment plants. In 2010 the production wells collectively withdrew about $0.9 \mathrm{Mgal} / \mathrm{d}$, which closely approximates their typical usage (Wisconsin Department of Natural Resources, 2013). The Waukesha plant, about $4 \mathrm{mi}$ upstream, discharges about 10-12 Mgal/d; farther upstream, the Brookfield plant discharges about $10 \mathrm{Mgal} / \mathrm{d}$ and the Sussex plant, about $2 \mathrm{Mgal} / \mathrm{d}$ (Tim Grundl, University of WisconsinMilwaukee, written commun., 2013). Enhancing selection of the site was the opportunity to provide supplemental data for related, but independent, studies of the site and upper Fox River by the USGS and the University of Wisconsin-Milwaukee (UWM).

The McHenry study site of approximately 14 acres (figs. 1; $3 B$ ) is about 2 mi west of the Fox River. The site is situated along the banks of an unnamed tributary to nearby Boone Creek (within about $0.05-0.1 \mathrm{mi}$ ) (fig. $3 C$ ) which, in turn, drains to the Fox River. This site was selected after a search for highcapacity wells operated within a short distance of the Fox River or its tributaries. Two production wells are present at the site as close as $140 \mathrm{ft}$ to the tributary and $275 \mathrm{ft}$ to Boone Creek, each with withdrawals of about $0.3 \mathrm{Mgal} / \mathrm{d}$ (Tim Bryant, Illinois State Water Survey, written commun., 2012). The search was restricted to McHenry County, as their water-resources program office was a cooperative partner in other USGS groundwater studies in the county. This allowed the opportunity to provide data and findings useful to the on-going cooperative studies and enhanced the possibility of expanding the study's scope by attracting additional research partners. 
$\boldsymbol{A}$

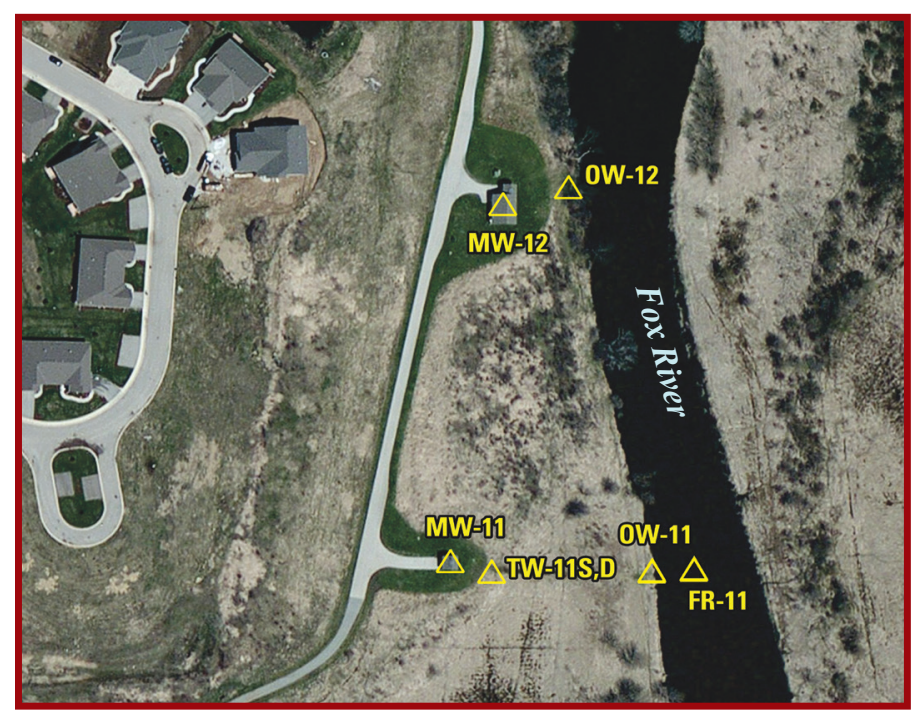

B

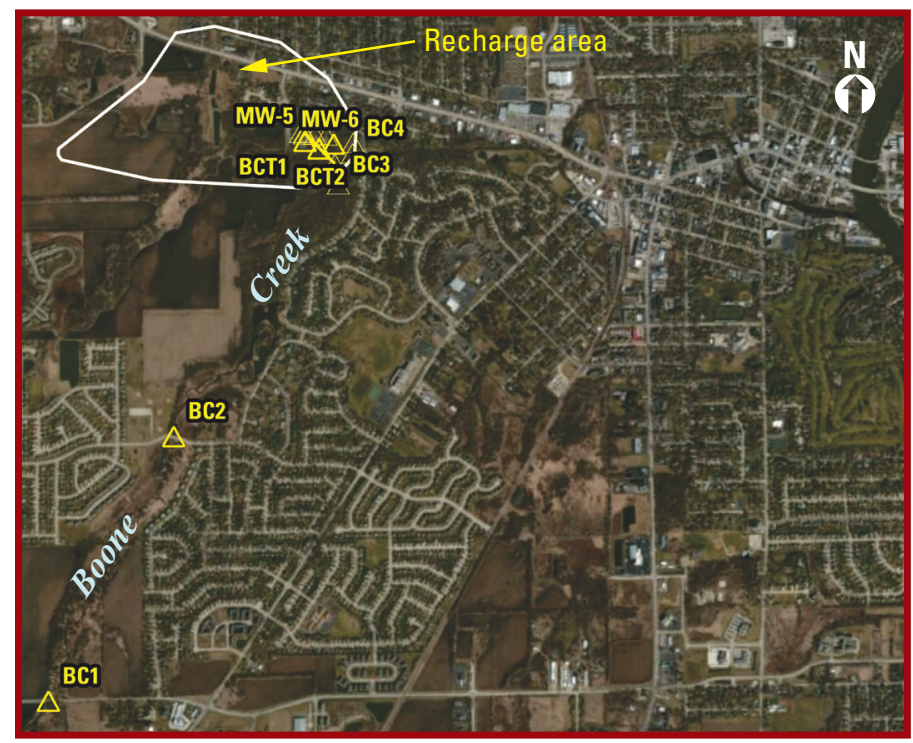

C

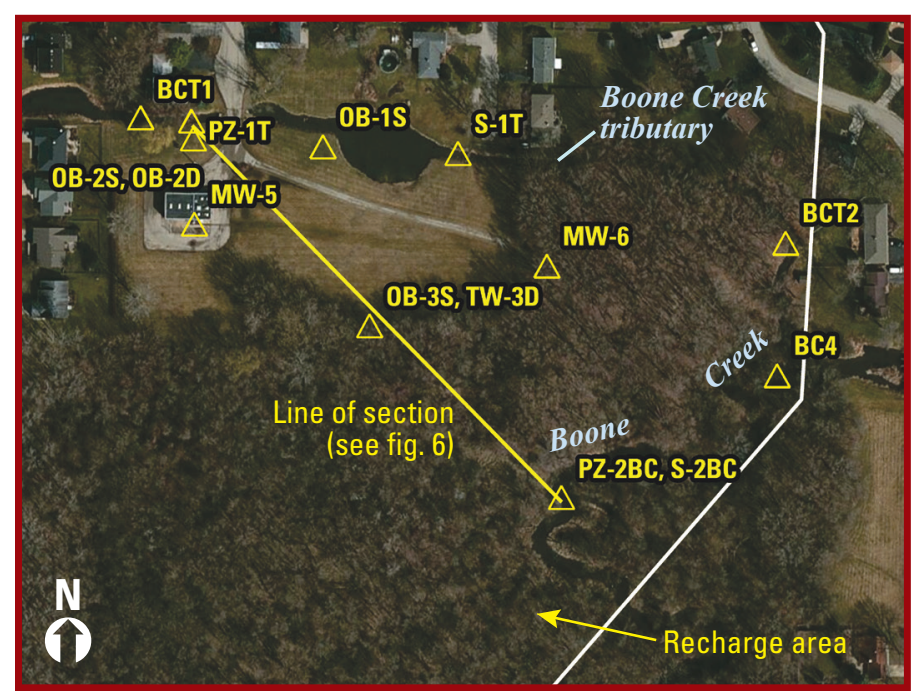

Base imagery from ArcGIS World Imagery Map Service, accessed July 2013 at http://services.arcgisonline.com/arcgis/services
Figure 3A. Waukesha, Wisconsin, site with production wells (MW), temporary wells (TW), observation well (OW), and Fox River sampling site (FR) (additional MW about 0.5 mile to the west).

Figure 3B. McHenry, Illinois, site with the Fox River and its tributaries, groundwater (well) and stream water-level and waterquality sampling sites, streamflow measurement sites (BC, BCT), and approximate recharge (capture) area of the production wells (modified from Illinois Environmental Protection Agency, 2013).

Figure 3C. McHenry, Illinois, site with production wells No. 5 and No. 6 (MW-5, MW-6), observation wells (OB-1S, OB-2S, OB-2D, OB-3S), temporary well (TW-3D), instream piezometers (PZ-1T, $\mathrm{PZ}-2 \mathrm{BC})$, stream sampling sites (S-1T, $\mathrm{S}-2 \mathrm{BC})$, and streamflow measurement sites (BCT1, BCT2, BC3, BC4).

Both study sites are composed of glacial deposits of about $100-150 \mathrm{ft}$ thickness that overlie dolomite of Silurian age. The glacial deposits consist of sand and gravel units of about $50-75 \mathrm{ft}$ thickness, with overlying and (or) interlying units of finer-grained sediments. Static depths to groundwater are less than $10 \mathrm{ft}$.

\section{Study Approach}

The intent of incorporating paired study sites was to use information obtained from the brief initial study at Waukesha to aid design of the more involved following study at McHenry. The Waukesha study focused principally on evaluation of study methods, which included determination of hydrologic data to be collected, instrumentation to be used, and water-quality constituents to be analyzed (table 1). There was only cursory evaluation of these data, with the limited aim of identifying obvious trends. Primarily, the data were used by the related studies at and near the Waukesha site to aid those more involved study efforts. The consistent and primary focus of field study at each study site was collection of various water-quality constituents at different horizontal and vertical points along a possible flow path(s) (transects) from the surface water bodies (river or tributaries) to the nearby production wells.

Study at the Waukesha site was completed during a single week in June 2010. Study at the McHenry site consisted of two principal field efforts, each of several days length. These were completed in October 2010 and June 2011. Additional periodic single-day site visits were made through 2012 to March 2013 to measure water levels and download data loggers. During much of 2012, most of Illinois was under drought conditions, with northern Illinois particularly affected during June 2012 through March 2013 (Arlan Juhl, Illinois Department of Natural Resources, written commun., 2013). 
Tracers to identify connections between groundwater and surface water-Molecules of elements having different atomic weights on the basis of their number of neutrons are referred to as isotopes. Those isotopes that do not disintegrate by radioactive decay are considered "stable." For example, the main stable isotopes that make up the water molecule are ${ }^{16} \mathrm{O},{ }^{18} \mathrm{O},{ }^{1} \mathrm{H}$, and $^{2} \mathrm{H}$. The isotopic behavior of some kinds of physical, chemical, or biochemical processes may be influenced by the relative weights of the isotopes. As such, the isotope makeup of an element in a water body, measured as a ratio of their quantities, makes for a potentially useful indicator of the history or source of the element (Hem, 1985). This ratio, when compared to an average or standard ratio, reflects the enrichment or impoverishment of a particular isotope, reported as the $\delta_{x}$ (per mil) value.

Table 1. Data-collection design for the Waukesha, Wisconsin, and McHenry, Illinois, sites. $A$, Hydrologic data and instrumentation. $B$, Water-quality constituents.

$\boldsymbol{A}$

\begin{tabular}{|lll|}
\hline \multicolumn{1}{c}{ Data type } & Waukesha & McHenry \\
\hline Geophysical logs & Limited & Limited \\
\hline Direct-push wells (TW) & Yes & Limited \\
\hline Observation wells (OW, OB) & Limited & Yes \\
\hline Instream piezometers (PZ) & No & Yes \\
\hline Production wells (MW) & No & Limited \\
Water levels-continuous & Limited & Yes \\
Water levels-periodic & Limited & Yes \\
Water temperature & No & Limited \\
Water quality & Synoptic & Synoptic \\
Streamflow & No & Synoptic \\
\hline
\end{tabular}

$\boldsymbol{B}$

\begin{tabular}{|lcl|}
\hline \multicolumn{1}{c}{ Constituent } & Waukesha & McHenry \\
\hline Field parameters & Yes & Yes \\
Major ions & Yes & Yes \\
Halogens & Yes & Yes \\
Stable isotopes & Yes & Yes \\
\multicolumn{1}{c}{ (Boron, hydrogen, oxygen) } & & \\
Pharmaceuticals & Yes & Surface water \\
Dissolved gases & Yes & No \\
Sulfur hexafluoride & Yes & No \\
\hline Nutrients & No & Yes \\
Nitrogen isotopes & No & No \\
\hline
\end{tabular}

${ }^{1}$ Samples analyzed by the U.S. Geological Survey (USGS) National Water Quality Laboratory (Lakewood, Colorado), associated USGS chlorofluorcarbon and stable isotope laboratories (Reston, Virginia), and a USGS isotope research laboratory (Menlo Park, California).

Waukesha-For the Waukesha site, groundwater sampling primarily relied on the use of temporary direct-push wells, installed using Geoprobe Systems methodology. The short duration of the study precluded the installation of permanent observation wells for sampling purposes. Near the completion of the study, two such wells (depths less than $20 \mathrm{ft}$ ) were installed on the banks of the Fox River (fig. 3A) for subsequent water-level measurements and possible water-quality sampling as part of the related studies.

The selected water-quality constituents were considered potentially useful as tracers, by their presence and concentration, to demonstrate any direct flow connection between the streams and the production-well withdrawals. The tracers included naturally occurring constituents that can be associated with treated wastewater, such as major and minor ions (sodium and boron, for example), halogens (chloride and fluoride, for example), and nutrients (nitrate, for example). Also included were anthropogenic compounds often associated with releases of treated wastewater, such as pharmaceuticals; and anthropogenic compounds and stable isotopes (Hem, 1985; Buszka and others, 2007; Kay and others, 2002) relevant to age dating and source tracking of water, such as sulfur hexafluoride (SF6) and ${ }^{11}$ Boron $(\mathrm{B}),{ }^{2}$ Hydrogen $(\mathrm{H})$, and ${ }^{18}$ Oxygen $(\mathrm{O})$. All waterquality sampling followed USGS protocols (U.S. Geological Survey, variously dated).

The three production wells, $105-144 \mathrm{ft}$ deep, are open to glacial sand-and-gravel deposits. Construction/geologic logs of the production wells and two observation wells, and electrical conductivity (EC) and penetration-rate (geophysical) logs obtained using the direct-push technique, were used to better describe the local geologic framework. When variations in porefluid chemistry are small, such as at the described study site, the electrical conductivity of saturated media is primarily a function of clay content (the greater the clay content, the higher the EC) (Keys, 1990).

As the exploratory Waukesha study described here primarily supplemented the efforts of the related USGS/UWM studies, this report hereafter principally will address the objectives, field efforts, and findings specific to the subsequent McHenry study. In brief summary of the multiple Waukesha studies, the exploratory data-collection effort provided no readily apparent evidence of streamflow inducement in the immediate vicinity of the riverside production wells. That effort did provide findings useful to the design of the subsequent McHenry study. The related Waukesha studies, which encompassed a larger area than the exploratory study, strongly indicated preferential inducement of streamflow occurs about $700 \mathrm{ft}$ downstream of the production-well study site through an apparent breach in the clay-rich aquitard that underlies the Fox River and vicinity (Tim Grundl, University of Wisconsin-Milwaukee, written commun., 2013). Elsewhere, the aquitard appears to hydraulically isolate the shallow sand-and-gravel groundwater system that includes the river channel from the deeper system tapped by the nearby production wells. Full details and findings of the related studies can be found in Feinstein and others (2012), which focused on groundwater-surface water flow simulation in the upper Fox River watershed; or by contacting Tim Grundl or Doug Cherkauer (UWM), who focused, in part, on the role of riverbank filtration (inducement) in sustaining groundwater supplies.

McHenry_-For the McHenry site, groundwater sampling primarily relied on the use of more permanent, conventionally installed (by auger) 2-in. diameter polyvinylchloride (PVC) 
observation wells (table 2; fig. 4). Their permanence and construction allowed for longer duration data collection with use of commonly available water-level recording pressure transducers and positive-displacement sampling pumps. To supplement this set of four observation wells, one temporary well (TW-3D; table 2; fig. 3C) subsequently was installed at mid-depth in the aquifer using the direct-push technique. Additionally, an instream piezometer was installed into the bed of the Boone Creek tributary and into Boone Creek (fig. 3C).

Table 2. Well information at the McHenry, llinois, site.

\begin{tabular}{|ccl|} 
Well name & $\begin{array}{c}\text { Screen depth below } \\
\text { land surface, in feet }\end{array}$ & \multicolumn{1}{c}{$\begin{array}{c}\text { Lithology at } \\
\text { screen depth }\end{array}$} \\
\hline PZ-1T ${ }^{1}$ & $1.1-2.9$ & Silt/clay \\
\hline PZ-2BC & ${ }^{3} 0.5-1.5 / 1.0-2.0$ & Silt/sand/pebbles \\
\hline OB-1S & $7.7-12.7$ & Silt/clay \\
\hline OB-2S & $9.0-14.0$ & Sandy silt/clay \\
\hline OB-2D & $42.9-47.9$ & Silty sand/gravel \\
OB-3S & $14.2-19.2$ & Silty sand/gravel \\
\hline TW-3D & $38.2-42.2$ & Silty sand/gravel \\
MW-5 & $70-95$ & Sand/gravel \\
\hline MW-6 & $97-124$ & Dolomite \\
\hline
\end{tabular}

${ }^{1}$ Boone Creek tributary.

${ }^{2}$ Boone Creek.

${ }^{3}$ Water year 2011 (October 1-September 30, 2011)/water year 2012-13.

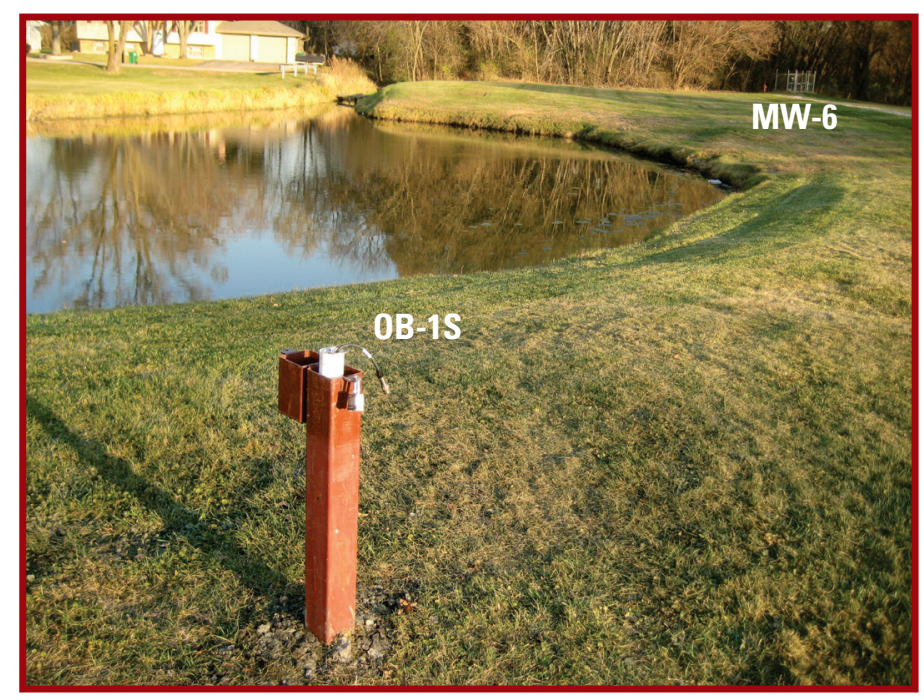

Figure 4. Observation well OB-1S (with installed pressure transducer/water-level data logger) and production well MW-6 adjacent to the Boone Creek tributary.

The focus of study at the McHenry site was considerably broader than at the Waukesha site. Included were assessments of the

(1) hydrogeologic framework of the production-well site; as determined from the available driller's logs from construction of production well MW-5, geologic cuttings obtained during installation of the study's observation wells, and electrical conductivity logging to near the base of the aquifer at the location of each observation well (fig. 5);
(2) groundwater responses to the nearby productionwell withdrawals; as determined by periodic and continuous measurement of water levels and groundwater temperatures at shallow and intermediate depths in the aquifer at three well clusters (OB-1S; OB-2S, OB-2D; OB-3S) located between the two production wells and the nearby Boone Creek tributary, a ponded reach on the tributary, and Boone Creek (figs. $3 C$; $6 A$ );

(3) groundwater/surface water responses within the local tributary reaches to the nearby well withdrawals; as determined by continuous measurement of water levels (and groundwater temperatures) within the instream piezometers and adjacent to the piezometers at the tributary beds (PZ-1T; PZ-2BC) (figs. 3C; 6B);

(4) streamflow responses that might reflect reductions in natural groundwater discharge and(or) streamflow capture induced by the nearby well withdrawals; as determined by repeated paired measurements of streamflow (often referred to as seepage runs) along a reach of Boone Creek tributary surmised to be affected by the nearby production-well withdrawals; and two separate reaches of Boone Creek, one surmised to be affected and the other unaffected by the withdrawals (figs. $3 C ; 6 C$ ); and

(5) possible flow paths from the tributaries to the nearby production wells; as determined by collection of selected water-quality constituents at different horizontal and vertical points from Boone Creek tributary and Boone Creek through shallow- and intermediate-aquifer-depth deposits, and to the production wells open to the base of the local sandand-gravel aquifer, and the top part of the uppermost Silurian dolomite bedrock aquifer (figs. $3 B, C ; 6 D ; 7$ ).

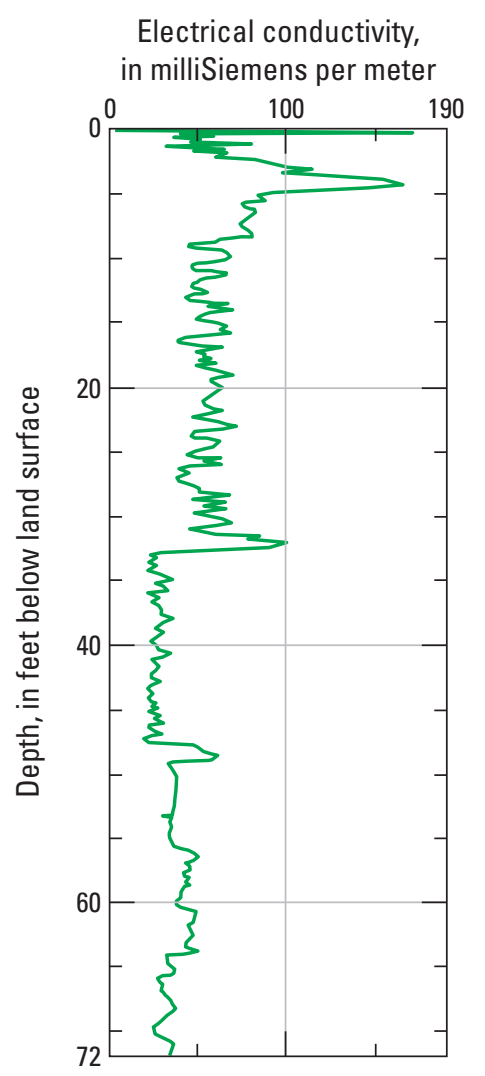

Penetration rate, in feet per minute

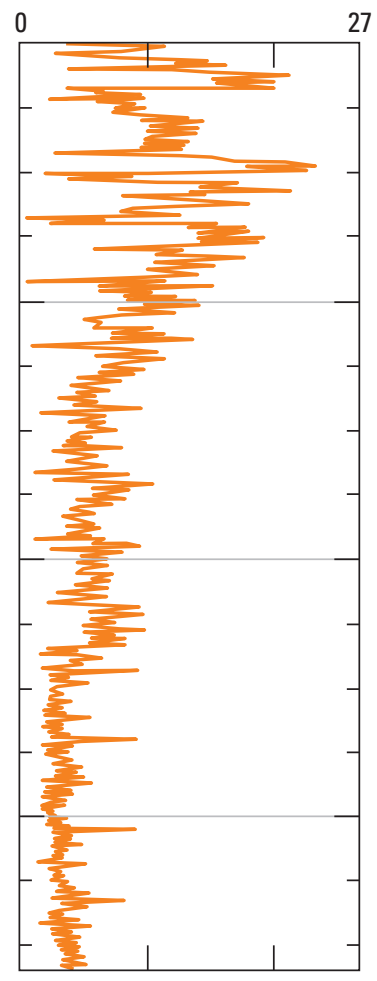

Figure 5. Geophysical logs collected at the McHenry, Illinois, site of well $0 B-2 D$. 


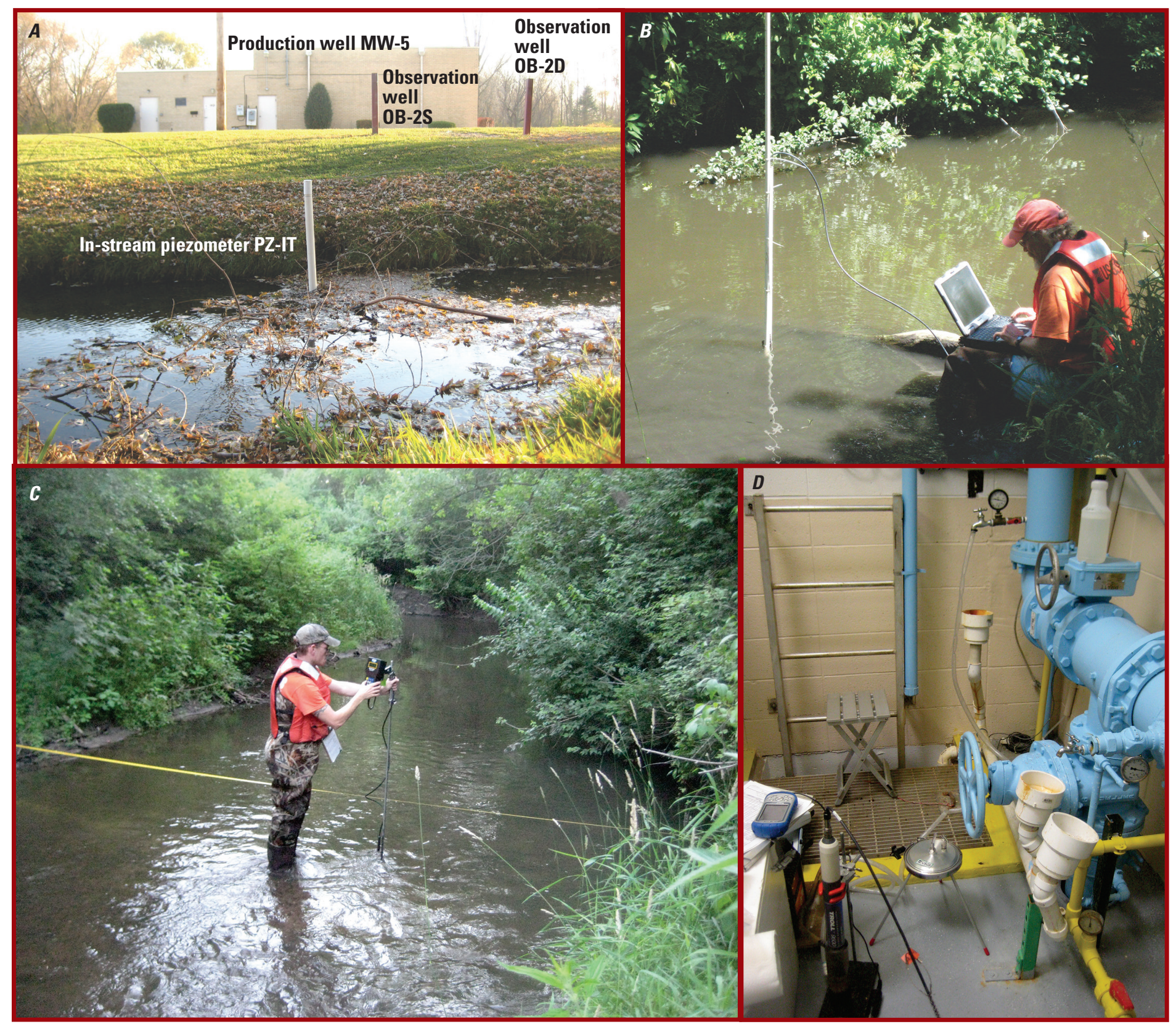

Figure 6. Representative data collection at the McHenry, Illinois, study site. A, Groundwater in and near the Boone Creek tributary. $B$, Groundwater-surface water relation in Boone Creek. $C$, Streamflow in Boone Creek. $D$, Water quality at production well MW-5.

Groundwater and tributary levels were measured periodically during October 2010 to March 2013. Groundwater and tributary levels and groundwater temperatures were collected at 5-minute intervals over periods of 10-60 days at select locations during October-November 2010, June-July 2011, August-September 2011, and August-October 2012. These data were used to determine vertical gradients and directions of flow between the tributaries and various depths within the groundwater system and their variability in relation to well-pumping cycles. Water-level measurements were made according to USGS protocol (Cunningham and Schalk, 2011) with calibration-checked electric tapes. Of note, evidence of water-level fluctuations in groundwater might only represent a transmitted pressure response to the nearby well withdrawals and not be directly indicative of actual flow of water between and within the tributaries and groundwater systems.
Use of temperature has been documented as an extremely useful means of better understanding the dynamics of streamgroundwater exchanges (Stonestrom and Constantz, 2004). Groundwater temperatures were measured at 5-minute intervals with the thermal sensor internal to the pressure transducers/ data loggers. The sensors were not calibrated specifically for this exploratory effort, but their output was considered acceptably accurate and appropriate for monitoring relative changes in temperature.

One to three repeated upstream-downstream pairs of streamflow measurements were made during June 28-29, 2011. Paired measurements coincided with periods of production well water withdrawals and periods with no withdrawals. The wells typically were in use from about 8:30 a.m. to 11:00 p.m. with pump rates of about 600-660 gal/min (Mike Palmer, McHenry, Illinois Department of Public Works, written commun., 2011). 


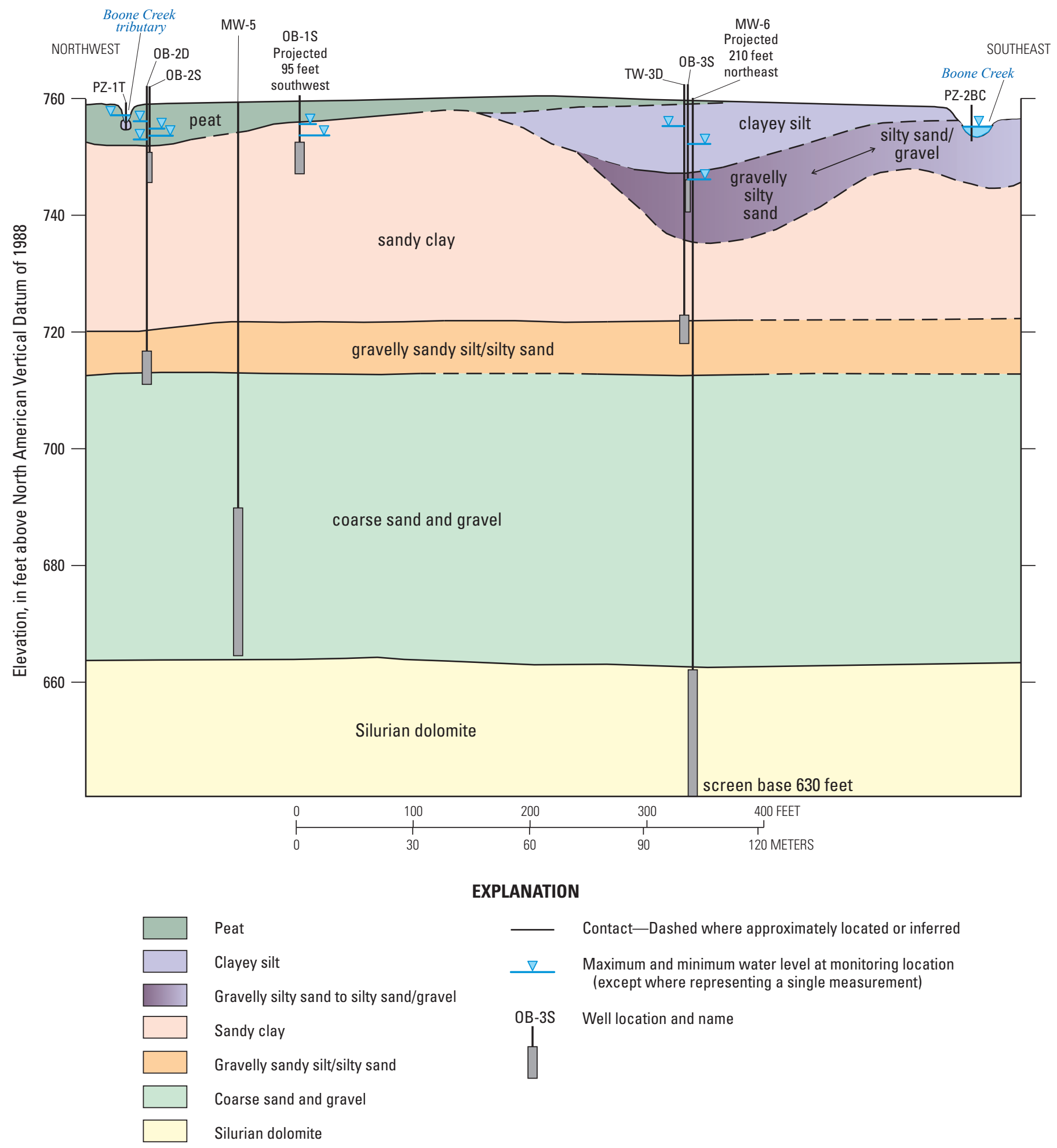

Figure 7. Geology, well-construction, and water levels at the McHenry, Illinois, site (line of section shown in figure $3 C$ ). 


\section{Groundwater-Surface Water Relations in the Fox River Watershed}

This pattern was altered on June 29, 2012, for groundwater sampling; there were no withdrawals by the wells until after about 2:00 p.m. Tributary reaches presumed to be affected and unaffected by these withdrawals were determined on the basis of groundwater modeling of contributing (recharge) areas to the production wells (Illinois Environmental Protection Agency, 2013) (fig. 3). In the absence of other inputs, such as from connecting tributaries or storm drains, gains or losses in streamflow within each measured tributary reach can be considered to result from groundwater discharge to the tributaries or tributary discharge to the underlying groundwater system, either associated with natural variability in the hydrologic and geologic characteristics of the surface water-groundwater systems (resulting in gains or losses) or in response to stressors, such as groundwater withdrawals (resulting in losses) (Winter and others, 1998). Temporal variability in those stressors might result in detectable variations in the magnitude and characteristics (gain-loss) of flow, and thus, document the impact of near-tributary withdrawals on natural groundwater discharge to the tributaries.

The water-quality constituents were considered potentially useful as tracers. By mapping of their presence and concentration gradients in groundwaters, the well withdrawals might be associated directly with tributary-sourced wastewaters.

Dissolved gases, including SF6, are often a useful means of age dating water for source tracking. Indications of water age and distinct differences in their stream-water and groundwater concentrations can be indicative of isolated shallow and deep groundwater systems with limited to no shallow groundwater and (or) stream-water contribution to well withdrawals. However, water samples at McHenry were not analyzed for these constituents. Findings from the earlier study in Waukesha indicated they were of no benefit, because of inappropriate hydrologic and geochemical conditions (and possibly sampling conditions). Similar interferences were expected at the McHenry site.

Tributary samples were collected from Boone Creek, adjacent to instream piezometer PZ-2BC, and from the Boone Creek tributary, at the outflow of the ponded reach. The outflow sample point was selected to collectively capture constituents associated with the tributary's presently active channel of flow and possibly constituents associated with past flow histories (including storm flows) that might have been entrained temporarily in the bed sediments or slack-flowage waters of the tributary's ponded reach (fig. 3C).

\section{Preliminary Findings}

The preliminary findings regarding the relation between surface water, groundwater, and well withdrawals at the McHenry, Ill., site are presented. These findings from the exploratory data-collection efforts in 2010-13 include the topics of site geologic framework, groundwater levels, hydraulic gradients, water-temperature patterns, stream-seepage patterns, and water chemistry/stable isotopes.

\section{Geologic Framework}

The sand-and-gravel deposits tapped by the production wells generally are distributed from a depth of about $40-100 \mathrm{ft}$ (fig. 7), with the uppermost of these deposits becoming increasingly more silty. These deposits are overlain by sandy clay deposits that range in thickness from about $35 \mathrm{ft}$ in the northern part of the site to about $15 \mathrm{ft}$ in the southern part. The thinning of these deposits appears to be related to erosion and deposition resulting from historical channel migration by Boone Creek. Well OB-3S lies at the edge of the creek's present topographically lower flood plain (by about $2 \mathrm{ft}$ ); overlying the clay deposits of glacial origin in this part of the site are coarsegrained deposits that appear to be of alluvial origin, with the deposits becoming increasingly finer grained progressively upward through the sequence. The uppermost clayey silt deposits common to the southern part of the site are replaced with loosely consolidated peat across much of the northern part.

\section{Groundwater Levels}

Periodically measured groundwater levels generally were within about $1 \mathrm{ft}$ of each other across the site and about $750 \mathrm{ft}$ above NAVD 88. Land surface at the site is about $758 \mathrm{ft}$ at well OB-1S, OB-2S, and OB-2D and $760 \mathrm{ft}$ at well OB-3S. Depths to water in all observation wells typically ranged within about 4.0-7.6 ft below land surface (fig. 8). The greatest recorded depths to water in all wells occurred in early fall 2012, during the height of the period of drought. For all wells, the decline was about $0.6 \mathrm{ft}$ beyond their maximum depth to water recorded at other times during the study. The maximum recorded depth to water during the study was $8.39 \mathrm{ft}$ at well OB-3S (September $20,2012)$. The water-level decline in fall 2012 is attributed to the drought-related reduction of natural recharge and the likely associated increase in groundwater withdrawals for landscape irrigation, swimming pool filling and replenishment, and similar seasonal uses.

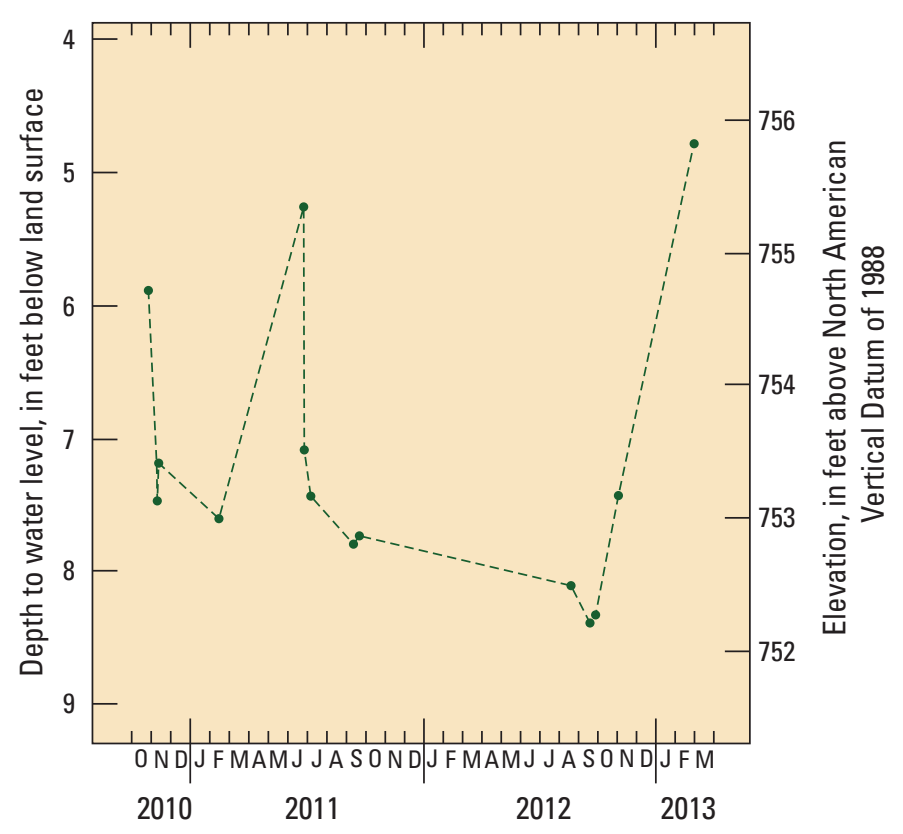

Figure 8. Hydrograph of well OB-3S, representative of periodically measured groundwater levels at the McHenry, Illinois, site, 2010-13. 
The shallowest recorded depths to water in all wells were in March 2013, when production well MW-5 had not been in use for about 6 months. These water levels were about $0.2-$ $0.5 \mathrm{ft}$ shallower than the previously recorded minimum depths at the wells in June 2011. The 2011 measurements followed an unusually wet spring when groundwater levels were shallower than their monthly normal levels (National Oceanic and Atmospheric Administration, 2011a,b). The smallest change in minimum water level, $0.18 \mathrm{ft}$ at well OB-1S, is attributed to its close proximity (about $25 \mathrm{ft}$ ) to the ponded reach of the Boone Creek tributary and tapping of permeable peat and alluvial deposits. It also is the shallowest of all wells and thus is presumably underlain by the greatest thickness of fine-grained deposits. These deposits further minimize response of the shallow groundwater levels at this location to production-well withdrawals.

The magnitude of the water-level response to the production-well withdrawals varies across the site, in apparent relation to depth within the sand-and-gravel deposits and thickness of the shallow clay-rich deposits (figs. $3 C$; 7; 9). The greatest water-level diurnal change associated with periods of pumping versus non-pumping was recorded at depth in the sandand-gravel deposits at well OB-2D, with typical fluctuations of almost $2.5 \mathrm{ft}$ when both production wells were in use and $0.75 \mathrm{ft}$ when one well was in use. Where the clay-rich deposits are thickest on the northern part of the site, little response to the withdrawals was evidenced in shallow wells open to these overlying fine-grained deposits. Of these wells, about $0.1 \mathrm{ft}$ of change was recorded at OB-2S and $0.05 \mathrm{ft}$ at OB-1S. The smaller response observed at well OB-1S (not shown) is attributed to its greater distance from the nearest production well (about $100 \mathrm{ft}$ ) and close proximity to the ponded reach of the Boone Creek tributary. In the southern part of the site, where the clay-rich strata are thinnest and possibly intermixed with seams of coarser sediments, typical fluctuations in the shallow well (OB-3S) closely approximated those of the deepest well (OB-2D). As indicated from the limited periods of record, the range of diurnal fluctuations in wells did not vary appreciably between "normal" and "drought" periods.

Periodically measured tributary water levels were suggestive of a response to nearby groundwater withdrawals, but evidence of this was inconsistent (fig. 9). Technical problems prevented measurement of groundwater levels beneath the bed of Boone Creek tributary in summer 2011. During the other periods of measurement in fall 2011 and fall 2012 there was no apparent response to the withdrawal activity. Changing stages in this water body may have masked any expectedly small response to withdrawals. In Boone Creek, groundwater levels beneath its bed were observed to fluctuate over respective ranges of about $0.05 \mathrm{ft}$ and $0.02 \mathrm{ft}$ during summer 2011 and fall 2012. Although these fluctuations are suggestive of a response to the nearby groundwater withdrawals, they could be related to diurnal cycles of evapotranspiration that limit groundwater
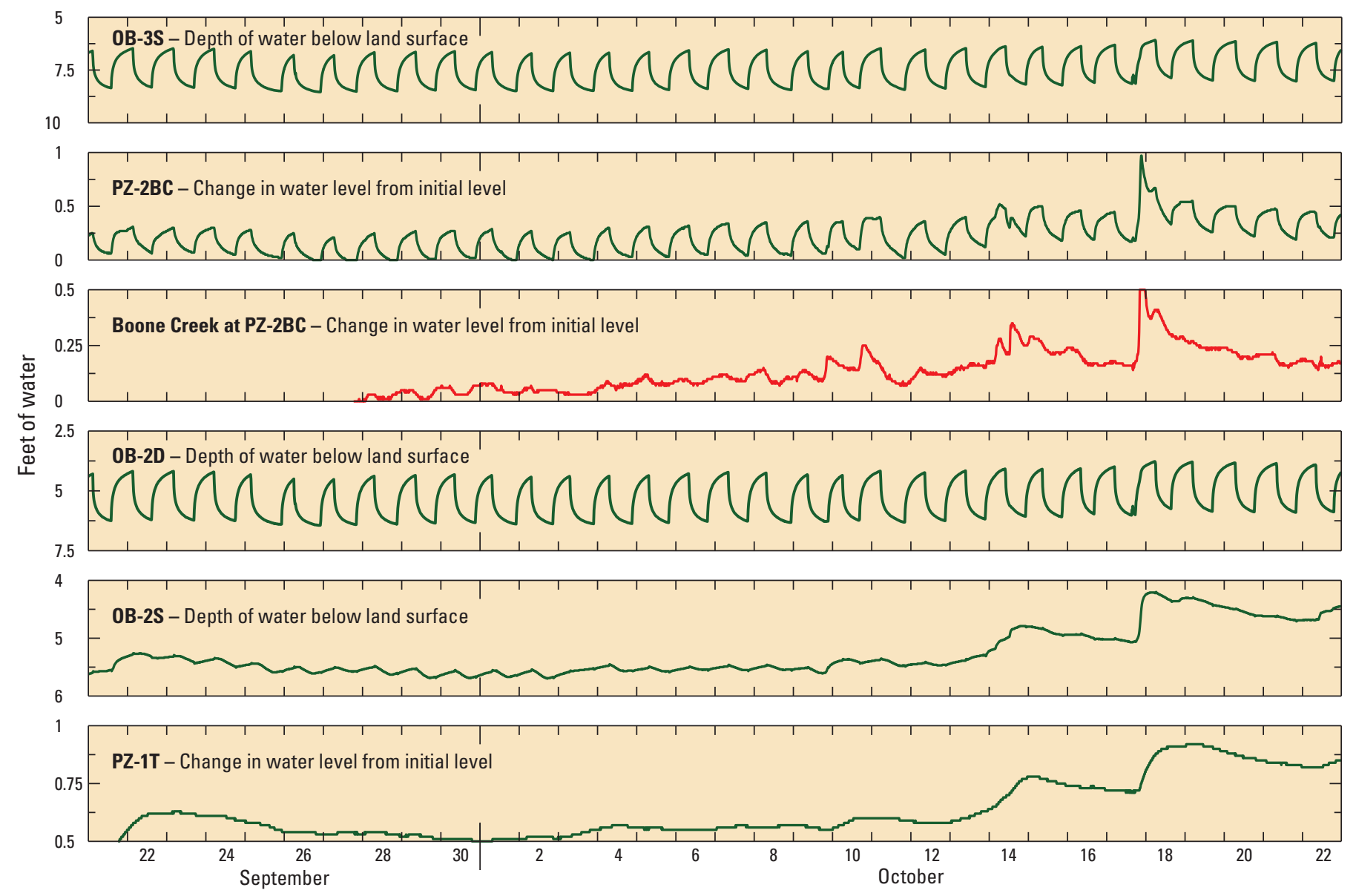

2012

Figure 9. Groundwater and stream levels in and near Boone Creek and its tributary at the McHenry, Illinois, site, September-0ctober 2012. 
discharge to streams (and, thus, streamflow) during warm season daylight hours (Lundquist and Cayan, 2002). The fluctuations also could be related to the observed diurnal-like fluctuations in streamflow/stage (level), although these fluctuations in the stage of Boone Creek generally were of smaller magnitude than those of groundwater, and sometimes out of phase.

\section{Hydraulic Gradients}

Over the 12 measurement dates in 2010-13 with paired data, vertical gradients at wells OB-2S/OB-2D indicated flow from the shallow to deeper parts of the groundwater system for 75 percent of the measurements. For 25 percent of the measurements, gradients indicated flow from the deeper to shallower parts of the aquifer; during these dates it is documented or suspected that nearby well MW-5 was not in use. With well measuring-point elevations not surveyed until March 2013 (when PZ-1T had been reinstalled into the bed of Boone Creek tributary with a different casing height than the damaged piezometer it replaced) only one accurate determination of vertical gradients between wells OB-2S/OB-2D and PZ-1T was possible. At this time, when well MW-5 had not been in use for several months, flow was indicated to be upward from the deep to shallow part of the groundwater system and from the shallow part to Boone Creek tributary. Vertical gradients approximated from water-level measurements at the originally installed PZ-1T (November 2010-September 2011) indicated flow to be downward from Boone Creek tributary to the shallow part of the groundwater system. During this period, well MW-5 typically was in use during the daylight hours when the water levels were measured.

Groundwater levels recorded in the beds of the Boone Creek tributary and Boone Creek and their relation to the surface water levels indicated varying response by location and time. Periodically measured levels to assess vertical gradients (thus, direction of flow) between groundwater and surface water indicated that, in the Boone Creek tributary, flow typically was from surface water to groundwater (table 3), likely the result of the nearby withdrawals of well MW-5. Differences in water levels (thus, vertical gradients) were weakest to non-existent in $2011(0-0.07 \mathrm{ft})$ and greatest in $2012(-0.12-0.89 \mathrm{ft})$. The measurements of September 20, $2012(0.89 \mathrm{ft})$, indicated disconnected groundwater and surface water systems, with the depth to groundwater measured as below the tributary bed. The measurements of March 1, $2013(-0.12)$, as previously discussed, occurred when well MW-5 was not in use and indicates natural groundwater discharge at this time was to the tributary. In the more remote Boone Creek (relative to the production wells), vertical gradients generally were weaker than those in the Boone Creek tributary. Notably, there was a reversal in gradient directions from year to year. This reversal indicates flow generally was from groundwater to surface water in 2011 (with differences in water levels of $-0.09-0.01 \mathrm{ft})$ and $2013(-0.14 \mathrm{ft})$ and from surface water to groundwater in $2012(0.11-0.12 \mathrm{ft})$. The changes in the magnitude and direction of the vertical flow gradients recorded at the two tributary locations seem associated, in part, with the dynamics of the noted drought and a presumed related increase in groundwater withdrawals. The generally larger gradients observed in the Boone Creek tributary

Table 3. Groundwater-surface water relations in Boone Creek (BC) and its tributary (BCT), McHenry, Illinois, site, 2010-13.

[SW $>\mathrm{GW}$, surface water to groundwater; $\mathrm{GW}>\mathrm{SW}$, groundwater to surface water; ND, no data; NG, no gradient; Below, bolded to highlight its singular occurrence]

\begin{tabular}{|c|c|c|c|}
\hline Date & Stream & GW height' ${ }^{1}$ & Vertical flow gradient \\
\hline \multicolumn{4}{|c|}{ Water year 2011} \\
\hline $11 / 09 / 2010$ & BCT & Above & $\mathrm{SW}>\mathrm{GW}$ \\
\hline $11 / 09 / 2010$ & $\mathrm{BC}$ & ND & ND \\
\hline $6 / 27 / 2011$ & BCT & Above & NG \\
\hline $6 / 27 / 2011$ & $\mathrm{BC}$ & Above & $\mathrm{GW}>\mathrm{SW}$ \\
\hline $7 / 08 / 2011$ & BCT & Above & $\mathrm{SW}>\mathrm{GW}$ \\
\hline $7 / 08 / 2011$ & $\mathrm{BC}$ & Above & $\mathrm{GW}>\mathrm{SW}$ \\
\hline $9 / 16 / 2011$ & BCT & Above & NG \\
\hline $9 / 16 / 2011$ & $\mathrm{BC}$ & Above & NG \\
\hline \multicolumn{4}{|c|}{ Water year 2012} \\
\hline $9 / 20 / 2012$ & BCT & Below & $\mathrm{SW}>\mathrm{GW}$ \\
\hline $9 / 20 / 2012$ & $\mathrm{BC}$ & Above & $\mathrm{SW}>\mathrm{GW}$ \\
\hline $9 / 27 / 2012$ & BCT & Above & $\mathrm{SW}>\mathrm{GW}$ \\
\hline $9 / 27 / 2012$ & $\mathrm{BC}$ & Above & $\mathrm{SW}>\mathrm{GW}$ \\
\hline \multicolumn{4}{|c|}{ Water year 2013} \\
\hline $3 / 01 / 2013$ & BCT & Above & $\mathrm{GW}>\mathrm{SW}$ \\
\hline $3 / 01 / 2013$ & $\mathrm{BC}$ & Above & $\mathrm{GW}>\mathrm{SW}$ \\
\hline
\end{tabular}

${ }^{1}$ Groundwater surface relative to streambed surface.

relative to those observed in Boone Creek are attributed to the fine-grained bed sediments of the tributary; these would more greatly restrict flow between the tributary and underlying groundwater than would the coarser-grained bed sediments of Boone Creek.

Hints of a potentially more pronounced influence of the well withdrawals on nearby streamflow can be seen in the limited vertical gradient data collected from the tributary beds under the conditions of the 2012 drought. The groundwater level in the Boone Creek tributary dropped below the streambed surface, gradients represented by stream and groundwater levels in Boone Creek reversed (suggesting a change from a gaining to a losing stream in this reach), and gradients in both tributaries notably increased over those observed in the more climatically normal period of 2011. In contrast to fall 2012, the gradients in both streams reversed in spring 2013, when well MW-5 was unused. For the only time observed during the study, the gradient in the Boone Creek tributary indicated discharge of groundwater to the tributary. During this period when only well MW-6 was in use, the gradient in Boone Creek reverted back to conditions that suggested discharge of groundwater to the stream. 


\section{Temperature Patterns}

Temperature patterns in groundwater provided some additional insight into the groundwater-surface water relations at the study site. Changes or fluctuations in groundwater temperatures were observed in all wells (fig. 10) and streambed piezometers (fig. 11). Paired water-level and temperature trends at the same well and piezometer locations have been compared to explore the possibility of their correlation. Groundwater temperatures tended to fall as groundwater levels fell during the mid-fall 2010 period of measurement (fig. 10A), tended to rise as groundwater levels fell during the midsummer 2011 period (fig. 10B), and tended to rise as groundwater levels rose during early fall 2012 (fig. 10C). However, during the seasonally different periods of monitoring (fall 2010, 2012; summer 2011), diurnal-like fluctuations suggestive of well-withdrawal cycles were observed in only a couple of observation wells (most notably OB-2D and OB-3S; figs. $3 C$; 7), and these apparent temperature responses were inconsistent both within and across the seasons of monitoring. For the most part, the observed fluctuations in the site wells of about $1{ }^{\circ} \mathrm{C}$ or less were not consistently observed or always in phase with the groundwater-level fluctuations or pumping cycles of the nearby wells, so it was difficult to parse out the possibly multiple stressors responsible for the fluctuations. That is, the fluctuations in temperature may be withdrawal induced, as active pumping adjectively draws warmer surface water into underlying cooler groundwater, the result of conductive transport of heat associated with daytime and nighttime (diurnal) fluctuations in air and surface water temperatures, or electronic noise of the thermal sensors. The groundwater beneath the streambed could be affected readily by such fluctuations in air and stream-water temperatures, given the shallow depth of the groundwater and its atmospheric exposure by way of the open-ended piezometer casings instrumented with the sensors.

The groundwater-temperature fluctuations observed beneath the beds of Boone Creek tributary and Boone Creek in fall 2011 and fall 2012 (fig. 11) were those most suggestive of a direct response to well withdrawals. Beneath the tributary beds these temperatures were observed to rise and fall as much as $6{ }^{\circ} \mathrm{C}$ along with the multi-day trends in groundwater levels. Also observed superimposed on the longer-term trends were shorter-term fluctuations in temperature of lesser magnitude that seemed to be diurnal and somewhat in phase with the cycles of nearby well withdrawals. These short-term fluctuations were as much as $1.5^{\circ} \mathrm{C}$ in the Boone Creek tributary (fall 2011) and $0.5^{\circ} \mathrm{C}$ in Boone Creek (fall 2012).
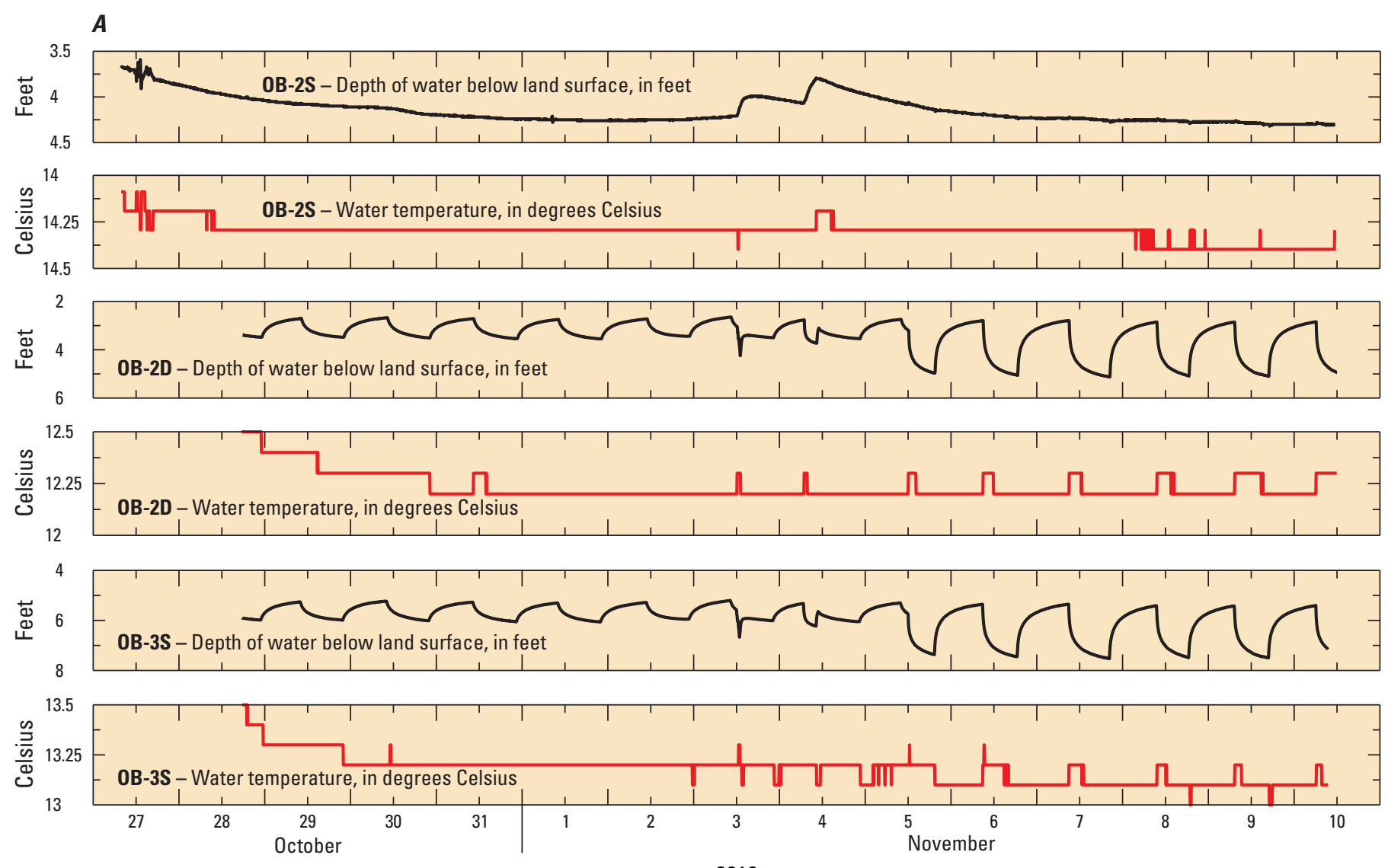

2010

Figure 10. Groundwater levels and temperatures near Boone Creek and its tributary at the McHenry, Illinois, site. A, October-November 2010. B, June-July 2011. C, September-October 2012. 

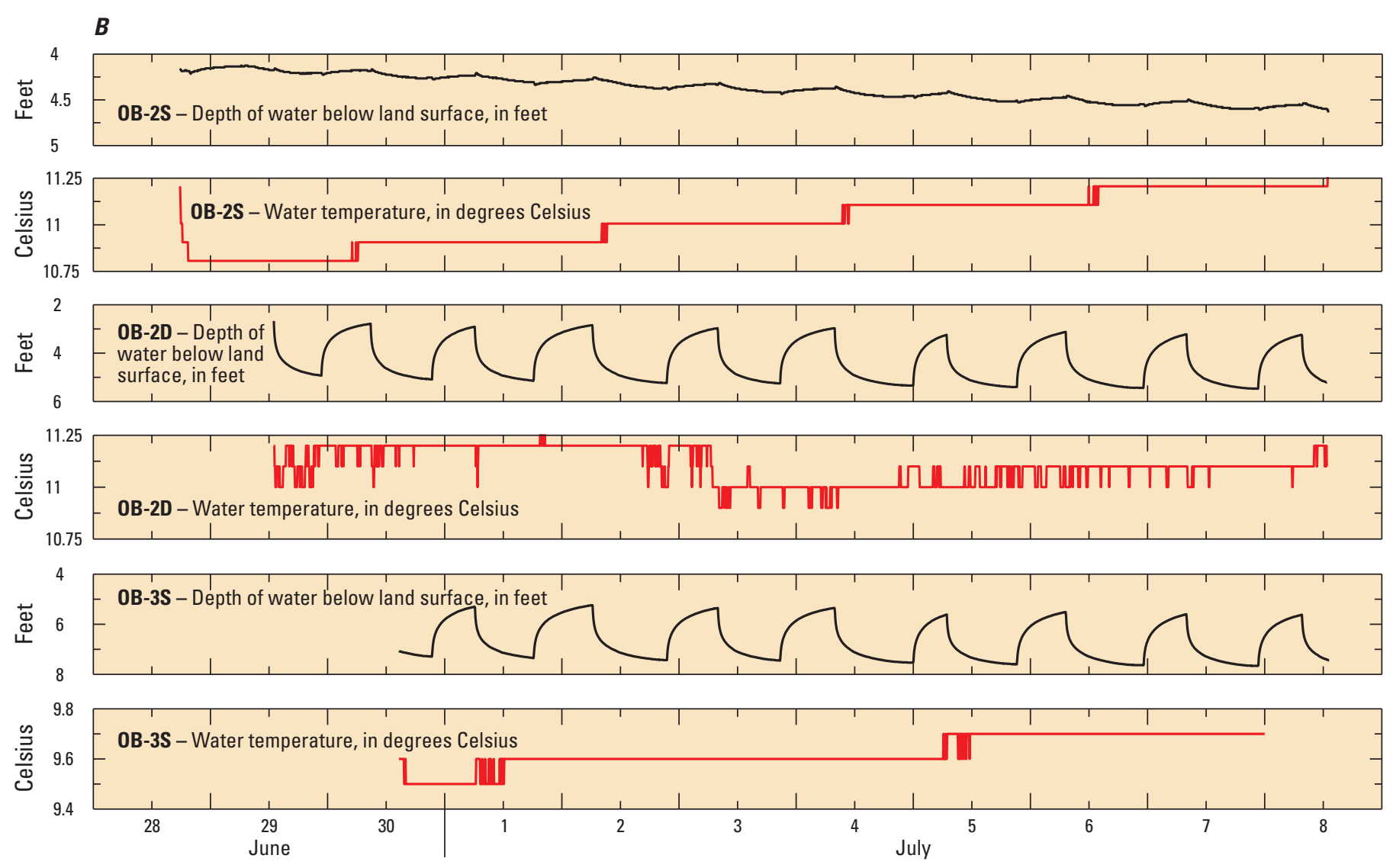

2011

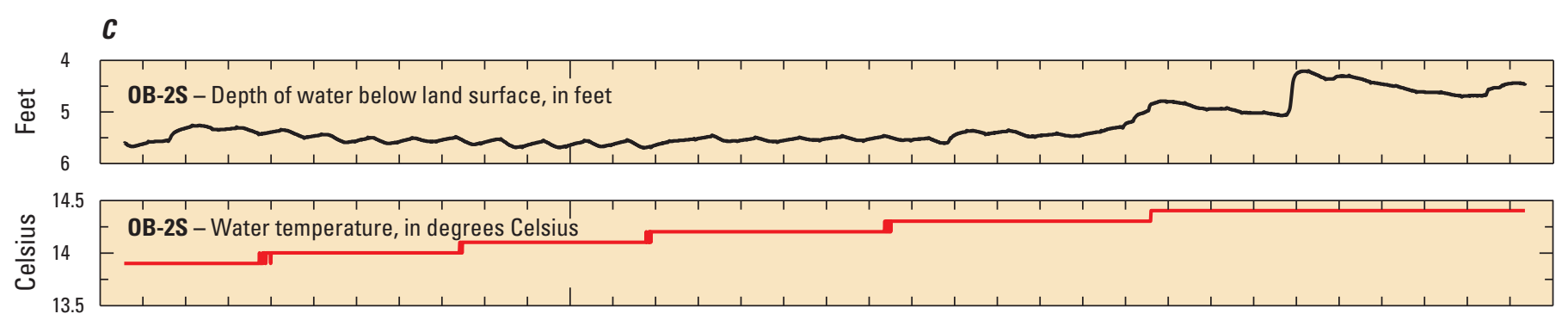

:

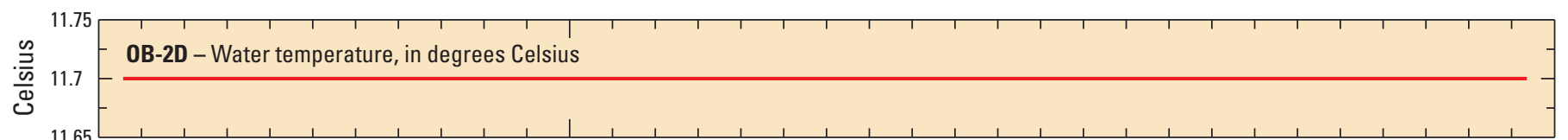

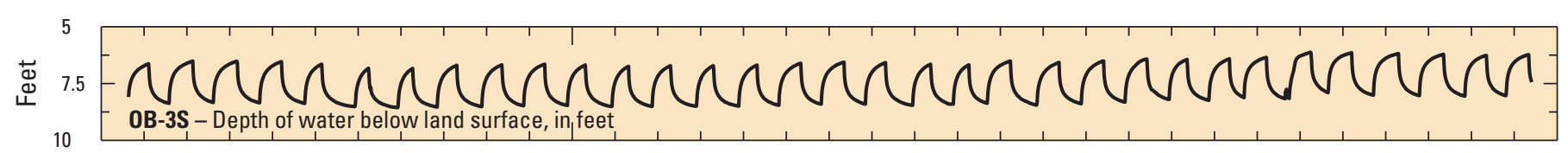

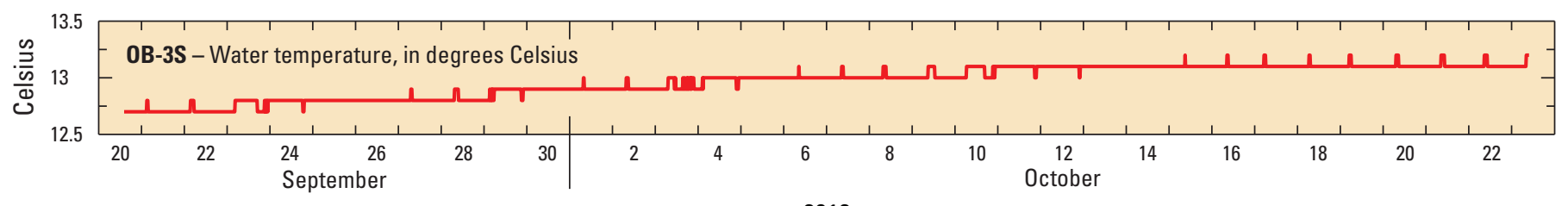

2012

Figure 10.-Continued Groundwater levels and temperatures near Boone Creek and its tributary at the McHenry, Illinois, site. A, October-November 2010. B, June-July 2011. C, September-0ctober 2012. 

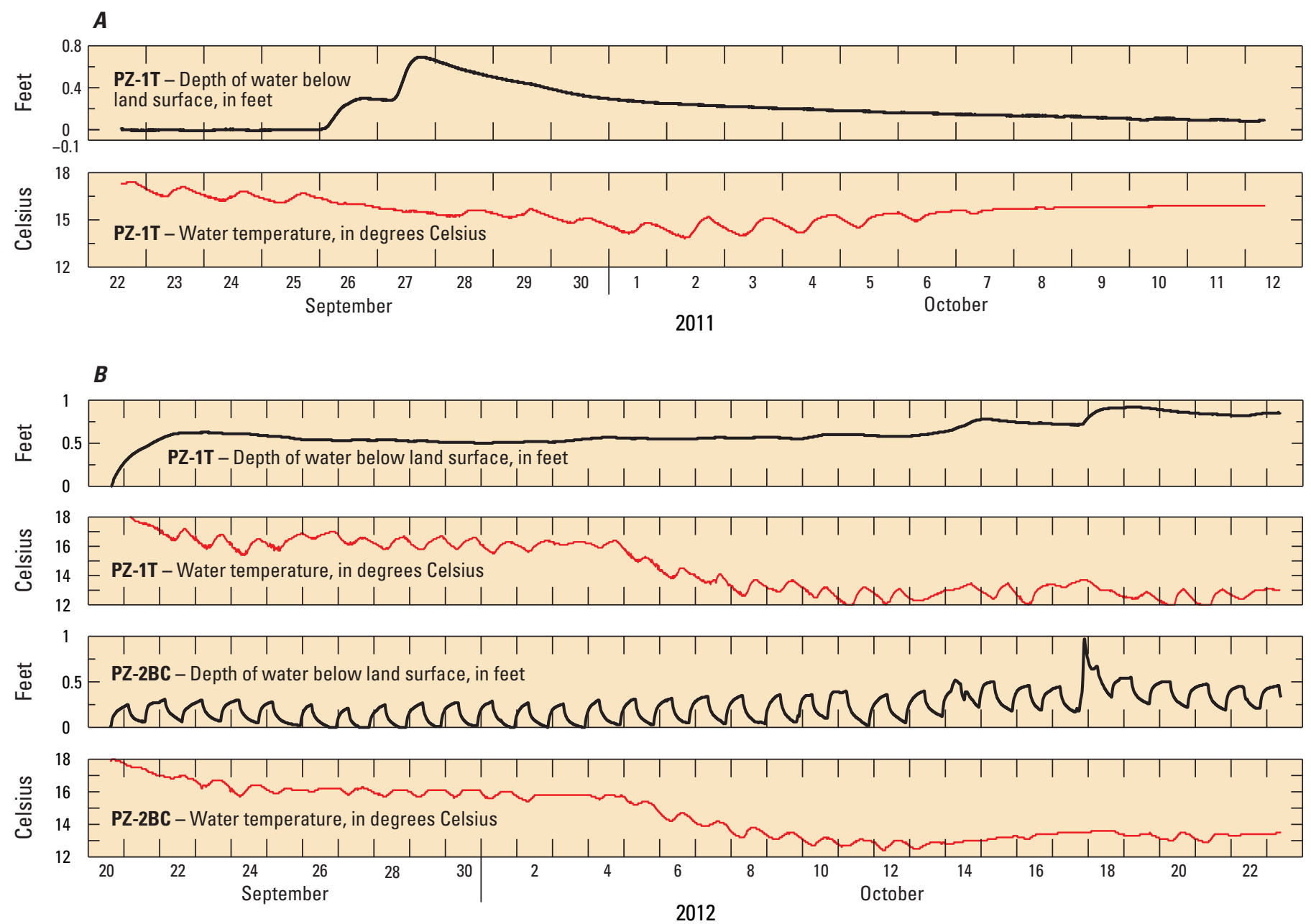

Figure 11. Groundwater levels and temperatures near Boone Creek and its tributary at the McHenry, Illinois, site. A, October-November 2010. B, June-July 2011. C, September-October 2012.

The fluctuations in temperature, however, were not always concomitant with short-term groundwater-level fluctuations. In some cases the temperature fluctuations seemed to occur in no apparent relation to groundwater levels. That is, fluctuations in temperature occurred when there was no apparent change in groundwater levels (PZ-1T; fig. 11A) or no fluctuations occurred despite obvious fluctuations in groundwater level (PZ-2BC; fig. $11 B$ ). The small magnitude of the groundwater-level fluctuations that were observed, particularly in the Boone Creek tributary (less than $0.1 \mathrm{ft}$ ), could account for the sometimes-seeming disconnect between tributary bed groundwater-level and temperature fluctuations. Despite the often slight and inconsistent manner of groundwater-temperature fluctuations beneath the tributaries and at various groundwater depths across the study site, it appears the well withdrawals may periodically result in some flow inducement from the nearby streams.

\section{Seepage Patterns}

Evidence of possible gains or losses to streamflow in the Boone Creek tributary and Boone Creek as a result of the nearby well withdrawals generally was inconclusive. Regardless of tributary reach, whether (1) within the possible recharge area limits of the production wells (fig. 3C; $\mathrm{BCT} 1 / \mathrm{BCT} 2$ and $\mathrm{BC} 3 /$ $\mathrm{BC} 4$ in table 4) or beyond those limits (about 1-2 mi) (fig. 3A; $\mathrm{BC} 1 / \mathrm{BC} 2$ in table 4 ), or (2) during pumping or nonpumping periods of the production wells, there were mixed results. For example, in background reach $\mathrm{BC} 1 / \mathrm{BC} 2$ the repeated measurements indicated the reach to be both losing flow to groundwater and gaining flow from groundwater during a period of pumping. Each of the stream reaches where the withdrawal effects might be detected was only about $1,000 \mathrm{ft}$ in length. As such, almost all of the small gains and losses in discharge rate that were measured were within the range of measurement error ( \pm 5 percent).

Only two individual upstream/downstream discharge measurement pairs identified changes in flow rate notably greater than 5 percent $(\mathrm{BC} 1 / \mathrm{BC} 2,6.3$ percent; $\mathrm{BC} 3 / \mathrm{BC} 4,-8.6$ percent) (table 4). By considering these more confidently representative measurements, a clearer pattern of streamflow response to wellwithdrawal activity becomes apparent. The background reach of Boone Creek, representing natural surface water-groundwater exchange in the vicinity of the study area, appears to be gaining flow from groundwater discharge. The reach of Boone Creek identified to be essentially within the simulation-defined recharge area of the production wells (fig. $3 C$ ) appears to be losing flow to groundwater when the wells are pumping and gaining flow from groundwater when pumping ceases. The reach of Boone Creek tributary identified to be within the simulationdefined recharge area of the wells seems to be neither losing nor gaining flow (no notable change) when the wells are pumping and weakly gaining flow when pumping ceases. 
Table 4. Streamflow measurements to assess gains and losses of base flow along select reaches of Boone Creek (BC) and its tributary (BCT), at and near the McHenry, Illinois, site, June 28-29, 2011.

$\left[\mathrm{ft}^{3} / \mathrm{s}\right.$, cubic foot per second; GW, groundwater; SW, surface water; MW, production well; L, losing (surface water to groundwater); G, gaining (groundwater to surface water); S, static; do., ditto; L and G bolded where measurement difference greater than 6 percent]

\begin{tabular}{|c|c|c|c|c|c|}
\hline Site & Date & $\begin{array}{l}\text { Difference in } \\
\text { discharge, in } \mathrm{ft}^{3} / \mathrm{s}\end{array}$ & $\begin{array}{l}\text { GW-SW } \\
\text { exchange }\end{array}$ & $\begin{array}{c}\text { GW withdrawal } \\
\text { activity }\end{array}$ & $\begin{array}{l}\text { Relation to MW } \\
\text { recharge area }\end{array}$ \\
\hline \multirow[t]{3}{*}{$\mathrm{BC} 1$ and $\mathrm{BC} 2$} & $6 / 28 / 2011$ & 0.3 & $\mathrm{~L}$ & Pumping & Beyond \\
\hline & do. & -.9 & $\mathbf{G}$ & Pumping & Beyond \\
\hline & $6 / 29 / 2011$ & -.3 & G & Nonpumping & Beyond \\
\hline \multirow[t]{6}{*}{$\mathrm{BC} 3$ and $\mathrm{BC} 4$} & $6 / 28 / 2011$ & .59 & $\mathrm{~L}$ & Pumping & Within \\
\hline & do. & .57 & $\mathrm{~L}$ & Pumping & Within \\
\hline & do. & 1.23 & $\mathbf{L}$ & Pumping & Within \\
\hline & $6 / 29 / 2011$ & .83 & $\mathrm{~L}$ & Nonpumping & Within \\
\hline & do. & -.74 & G & Nonpumping & Within \\
\hline & do. & -.17 & G & Nonpumping & Within \\
\hline \multirow[t]{5}{*}{ BCT1 and BCT2 } & $6 / 28 / 2011$ & .01 & $\mathrm{~S}$ & Pumping & Within \\
\hline & do. & .01 & $\mathrm{~S}$ & Pumping & Within \\
\hline & $6 / 29 / 2011$ & -.08 & $\mathrm{G}$ & Nonpumping & Within \\
\hline & do. & -.1 & G & Nonpumping & Within \\
\hline & do. & -.14 & G & Nonpumping & Within \\
\hline
\end{tabular}

${ }^{1}$ Recharge area determined from numerical simulation by the Illinois Environmental Protection Agency (2013).

\section{Water Chemistry}

Prescreening of the Boone Creek tributary and Boone Creek for anthropogenic wastewater compounds found no evidence of their presence in these surface water bodies. Thus, no samples were collected from groundwater for analyses of these compounds. The compounds, which include pharmaceuticals and caffeine and are often found in direct discharge to streams from wastewater-treatment processes, can be very useful tracers for identifying directly induced flow connections between streams and production wells.

Field characteristics of water and concentrations of major and minor ions, such as chloride and boron, provided inconsistent evidence of water-chemistry gradients between the site streams and groundwater at depth; such evidence might be indicative of streamflow inducement by the production-well withdrawals. Boron, often associated with detergents, and thus treated wastewater, was detected at concentrations of about $30-80 \mu \mathrm{g} / \mathrm{L}$. There was no discernible relation to water source (surface water or groundwater) or depth of groundwater. As evidence of somewhat isolated surface water and groundwater systems, the $\mathrm{pH}$ of both tributaries was above 8 units, whereas $\mathrm{pH}$ was below 7.5 units in all groundwaters; nitrate concentrations were above $0.2 \mathrm{mg} / \mathrm{L}$ in both tributaries and was less than $0.02 \mathrm{mg} / \mathrm{L}$ in all but one near-stream well sample $(0.03 \mathrm{mg} / \mathrm{L})$; and iron concentrations were less than $15 \mu \mathrm{g} / \mathrm{L}$ in both tributaries and greater than $1,300 \mu \mathrm{g} / \mathrm{L}$ in all groundwater samples. Although the water-chemistry data suggest generally isolated flow systems, their variability and range indicate that the extent of isolation might vary locally. Collection of background groundwater chemistry samples, which were not included in the study, presumably would have helped clarify interpretation of the various available water-chemistry data and, thus, understanding of the hydrodynamics at the site, including groundwater-surface water relations.

\section{Stable Isotopes}

For nitrogen, the highest $\delta^{15} \mathrm{~N}$ values typify septic sources (Heaton, 1986). Such elevated values in surface waters, particularly urban waters, typically result from wastewater discharge. However, because nitrate was essentially undetected in groundwater at the site, isotopic nitrogen could not be used to trace the source of waters in groundwater and withdrawn by the production wells.

Treated wastewaters and domestic wastewaters generally fall within the $\delta^{11} \mathrm{~B}$ (boron) range of about $0-12$ per mil (Bassett and others, 1995; Buszka and others, 2007; Thomas Bullen, U.S. Geological Survey, written commun., 2012). Shallower groundwaters and surface waters at the study site fell in the lower part of this range $\left(\delta^{11} \mathrm{~B}, 3.1-5.5\right.$ per mil). A possible anthropogenic source of boron suggested by the shallow water $\delta^{11} \mathrm{~B}$ values is detergents discharged from domestic septic systems in the Boone Creek watershed, as there are no public treatment releases of wastewater upstream of the study site. Deeper groundwaters represented by samples from wells OB-2D, TW-3D, and MW-6 (figs. 3C; 7) were notably more enriched (heavier) in ${ }^{11} \mathrm{~B}$ with respect to ${ }^{10} \mathrm{~B}\left(\delta^{11} \mathrm{~B}, 14.4-15.5\right.$ per mil) than the shallower waters (table 5; fig. 12). This enrichment at depth is indicative of marine carbonates and sediment surfaces that have been in contact with seawater in their past (Thomas Bullen, U.S. Geological Survey, written commun., 2012) and considered not representative of wastewater affected groundwater. The notable disparity of the $\delta^{11} \mathrm{~B}$ values representing the shallow and deep water systems of the site suggest that water movement between the systems generally is restricted. The intermediary clay-rich deposits appear to account for the restricted flow. 
Table 5. Isotopic chemistry of groundwater and surface water, McHenry, Illinois, site, June 27-30, 2011.

\begin{tabular}{|cccc|}
\hline Sample site & $\delta^{2} \mathbf{H}$, per mil & $\delta^{18} \mathbf{0}$, per mil & $\delta^{11} \mathbf{B}$, per mil $^{\mathbf{3}}$ \\
\hline OB-1S & -9.29 & -60.95 & 3.3 \\
\hline OB-2S & -8.35 & -54.34 & 3.2 \\
\hline OB-2D & -8.16 & -54.93 & 14.4 \\
\hline OB-3S & -8.20 & -53.60 & 4.0 \\
\hline TW-3D & -8.22 & -54.57 & 15.5 \\
\hline MW-5 & -8.27 & -53.35 & 3.1 \\
\hline MW-6 & -8.13 & -53.40 & 15.3 \\
\hline S-1T & -6.45 & -44.14 & 4.0 \\
\hline S-2BC & -7.47 & -50.65 & 5.5 \\
\hline
\end{tabular}

${ }^{1}$ Hydrogen ${ }^{2} \mathrm{H} /{ }^{1} \mathrm{H}$.

${ }^{2}$ Oxygen ${ }^{18} \mathrm{O} /{ }^{16} \mathrm{O}$.

${ }^{3}$ Boron ${ }^{11} \mathrm{~B} /{ }^{10} \mathrm{~B}$ relative to National Institute of Standards and Technology 951. ${ }^{4}$ Boone Creek tributary.

${ }^{5}$ Boone Creek.

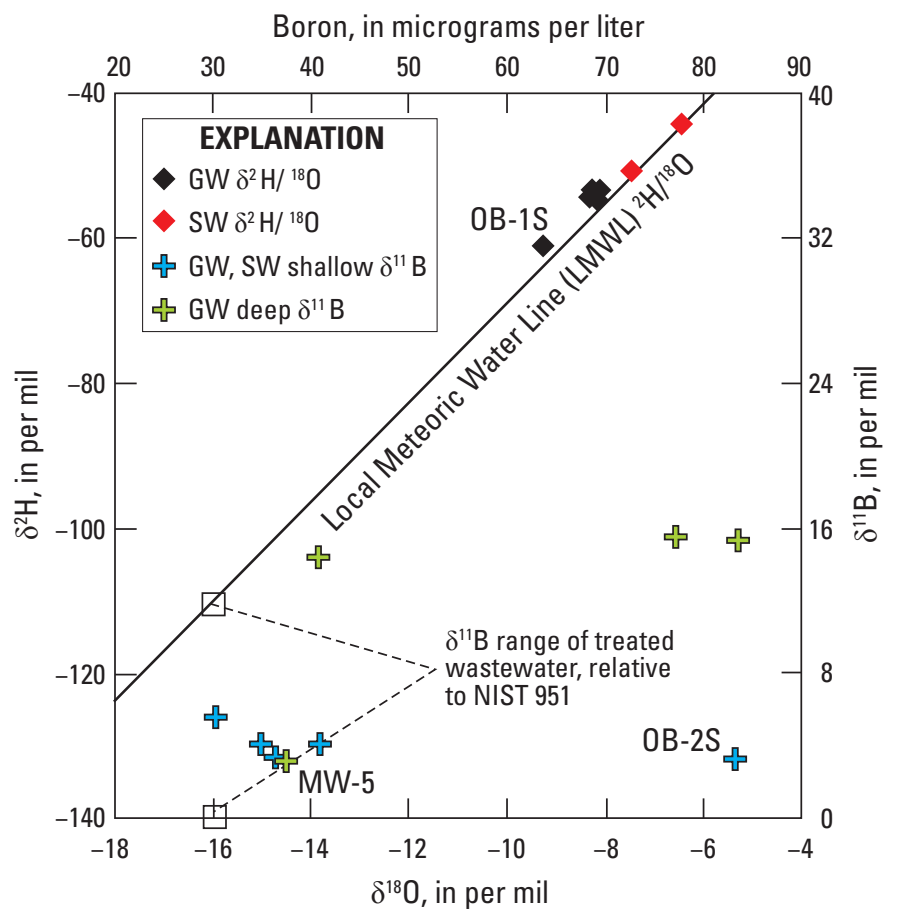

Figure 12. Isotopic composition of precipitation (LMWL), stream water (SW), and groundwater (GW) at the McHenry, Illinois, site, July 2011 (LMWL derived from precipitation data collected at Midway Airport, Chicago, III., (Kay and others, 2002); NIST, National Institute of Standards and Technology; $\delta^{11} B$ range (Bassett and others, 1995; Buszka and others, 2007, and Thomas Bullen, U.S. Geological Survey, written commun., 2012)).

The notably different isotopic composition of boron for sample waters withdrawn by wells MW-5 and MW-6 suggest that the primary source of deep recharge to these wells might differ. The isotopically lighter water from MW-5 $\left(\delta^{11} \mathrm{~B}, 3.1\right.$ per mil) compared to that from MW-6 ( $\delta^{11} \mathrm{~B}, 15.3$ per mil) suggests a preferential pathway for capture of near-surface groundwater or surface water might be present in the vicinity of well MW-5.
West of the well, in the core of the Illinois Environmental Protection Agency-simulated recharge area (fig. $3 B$ ), there are a number of ponds and a small stream. Thinning or absence of the underlying clay-rich deposits in this area would enhance the potential for inducement of flow from the shallow groundwater system and (or) the surface water bodies in response to the production-well withdrawals

The difference in the mass of hydrogen $(\mathrm{H})$ and oxygen (O) isotopes in water results in distinct partitioning of the isotopes (fractionation) as a result of evaporation, condensation, freezing, melting, or chemical and biological reactions. For example, $\delta^{2} \mathrm{H}$ and $\delta^{18} \mathrm{O}$ values in precipitation are isotopically lighter (lower del values) in areas with lower mean annual temperature. Strong seasonal variations are expected at any given location (Dansgaard, 1964). Average annual values of $\delta^{2} \mathrm{H}$ and $\delta^{18} \mathrm{O}$ in precipitation, however, show little variation at any one location. The $\mathrm{H}$ and $\mathrm{O}$ isotope compositions determined in waters of the study site can be compared to their regional longterm (1962-79) composition in precipitation, as determined at Midway Airport located about $50 \mathrm{mi}$ southeast of the site. The isotopic composition of the precipitation, as collected and analyzed by the International Atomic Energy Agency (Kay and others, 2002), is assumed to be equivalent to that of the precipitation at and near the study site. The values of $\delta^{2} \mathrm{H}$ and $\delta^{18} \mathrm{O}$ correlate with air temperatures with the lowest values in January and the highest values in July. Plotting values of $\delta^{2} \mathrm{H}$ and $\delta^{18} \mathrm{O}$ in precipitation at Midway Airport shows a direct covariance in the $\mathrm{H}$ and $\mathrm{O}$ isotopic composition of precipitation at the study site, as described by the equation:

$$
\delta^{2} H=6.98^{18} \mathrm{O}+0.08 \text { per mil }
$$

This equation describes the local meteoric water line (LMWL) and provides a reference with which the isotopic composition of groundwater at the study site can be evaluated. In shallow groundwater systems with temperatures of less than $50^{\circ} \mathrm{C}$, such as are present at the study site, the isotopic compositions of $\delta^{2} \mathrm{H}$ and $\delta^{18} \mathrm{O}$ in water are not affected by water/rock interactions (Perry and others, 1982), and these stable isotopes can be used as tracers. Differences in the isotopic composition of groundwater and precipitation, therefore, can be used to detect differences in source water.

Plotting of values of $\delta^{2} \mathrm{H}$ and $\delta^{18} \mathrm{O}$ for the surface water and groundwater samples at the study site shows that the samples plot near the LMWL at its isotopically heavier end (fig. 12). This indicates that groundwater throughout the vertical extent of the local unconsolidated deposits and uppermost part of the dolomite bedrock consists principally of recharge from modern (postglacial) precipitation that has not been substantially affected by evaporation or chemical or biological reactions.

Although the measurements of $\delta^{2} \mathrm{H}$ and $\delta^{18} \mathrm{O}$ in both the surface waters and groundwater of the site occurred within a limited range of values, the marginally heavier species of these elements were most abundant in the surface waters (table 5). This abundance likely results from the normally greater exposure of the surface waters to high seasonal temperatures and evaporation, particularly considering the samples were collected in late June (2011). The isotopically similar shallow and deeper groundwater isotopic values that differ somewhat from those of surface water suggest limited to moderate surface 
water movement to depth in the groundwater system under the assumed influence of the nearby withdrawals. Greater distinction between isotopically lighter and heavier waters would be expected in well-isolated shallow and deep flow systems with limited deep infiltration of surface waters.

\section{Conclusions and Lessons Learned}

The described exploratory studies, particularly the McHenry, Ill., study, document the benefits of using various approaches to evaluate the extent of surface water-groundwater exchange as affected by nearby high-capacity well withdrawals. Considered separately, each approach used at the McHenry site provided inconsistent findings that hindered characterization of the hydrodynamics of the groundwater-surface water flow systems. Periodic and continuous measurements of groundwater levels suggest that withdrawals variously can affect the level of groundwater as shallow as that closely beneath the nearby tributaries, with the observed affect most evident in the southern part of the site nearest to Boone Creek. Groundwater-temperature data appear to support these findings. Together, the groundwater-level and temperature data further suggest the surface waters of Boone Creek might respond to the nearby well withdrawals. The mapped geology of the site additionally complements these findings. The flow-restricting, clay-rich deposits that overlie the sand-and-gravel deposits tapped by the production wells thin in the southwestern part of the site, with the sand-and-gravel deposits occurring at a shallower depth than at site locations further removed from and outside the floodplain of Boone Creek.

The streamflow-measurement (seepage) data, somewhat indicating periodic, localized loss of streamflow in Boone Creek, provide more evidence of the stream's likely contribution of recharge to the underlying groundwater system during active pumping of the nearby production wells. Furthermore, when considered collectively, the seepage, water-level, and geologic data suggest the possibility of preferential inducement of streamflow within the reach of Boone Creek near and upstream of instream piezometer PZ2-BC, which lies within the area contributing recharge to the nearby production wells (fig. $3 C$ ). The coarse sediments that compose the creek's streambed and underlying glacial deposits could, if extensively thick, provide a hydraulic pathway for induced flow, particularly where nearest to well MW-6.

Much of the water-chemistry data suggested the surface water and groundwater systems are, for the most part, hydraulically isolated. However, the isotopic data further indicated the likelihood of limited to moderate hydraulic connection between the shallow and deep groundwater systems with possible preferential inducement of surface waters from streams and ponds west of well MW-5 (fig. 3C).

The inconsistent findings of the various data components of the McHenry study appear, in part, to be associated with the temporal variability of the system being studied. The limited temporal and spatial distribution of the water-chemistry and hydrologic data collection for the exploratory effort seemingly was insufficient to fully account for this variability and best characterize the hydrodynamics of the groundwater-surface water flow systems and influence of the production-well withdrawals.
The production wells at the site are mostly offline during evening hours; most of the data were collected during daylight hours when the wells are operating. Water-quality data were collected during a single midsummer synoptic, with no data collected from background locations unaffected by well withdrawals and(or) possible interaction with streamflow. Additional surface water and groundwater sampling and water-level measurement throughout the daily cycle of well operation and over longer time frames representative of seasonal and climatic variability might have ensured that possible temporal lags in water chemistry relative to the full cycle of withdrawal activity were identified.

Any future data collection and analysis efforts at the McHenry site might consider addressing remaining questions regarding (1) background water chemistry, with a focus on the area southwest of well MW-5; (2) possible preferential inducement of streamflow to the production wells from the reach of Boone Creek near well MW-6; and (3) possible preferential shallow groundwater recharge and (or) inducement of streamflow to well MW-5 from an area west of the well.

Increased demand for water in the Fox River watershed in future years is expected to increasingly impact the regionally important Fox River (Meyer and others, 2009), which could limit its capacity for accommodating the demand. Collectively, the exploratory studies at the McHenry, Ill. and Waukesha, Wis. sites, and the related Waukesha-area studies, indicated that withdrawals in close proximity of the Fox River and its tributaries are reducing natural groundwater discharge to and removing water from the river system. Further study at the McHenry site and other similar sites would augment understanding of the extent of this impact within the watershed and the conditions (hydrogeology and well operation) that most influence the groundwater-surface water relations.

Several useful lessons for future such studies were identified from the paired studies conducted in McHenry and Waukesha.

- Use of water-quality indicators to assess occurrence and extent of surface water-groundwater exchange might be enhanced by collection of

- multiple indicators, including stable isotopes, to more fully address the complexity of the flow systems and clarify data interpretation,

- selected screening samples of surface water and groundwater to help identify those water-quality indicators that might have the greatest potential for beneficial results,

- background groundwater samples collected (1) upgradient of the production well, opposite of any probable flow path between that well and the surface water body, and (2) outside the area contributing recharge to the production well, and

- selected water samples over time, particularly of analytes that might be affected by seasonal changes in temperature.

- Continuously recorded groundwater temperatures can be a useful assessment tool that can be collected inexpensively and easily. More advanced understanding of surface watergroundwater exchanges likely could result from application of emerging methodologies, such as 
- distributed temperature sensing (DTS), in which fiber-optic cables can be used to "continuously" measure temperatures to $0.01{ }^{\circ} \mathrm{C}$ in space and time at resolutions of 1 meter and seconds-to-hours (Stonestrom and Constantz, 2004).

- Although temporary wells installed by the direct-push technique typically are a cheaper alternative to installation of conventional monitoring wells, they can

- limit studies to a synoptic effort(s),

- depending on drill-rod size and size of conventional field tools,

- prevent continuous measurements of water-levels and other physical field parameters (temperature, dissolved oxygen, for example), and

- limit the array of useful water-quality indicators by restricting sampling-equipment options (such as use of positive displacement pumps with appropriate pumping rates).
- Electrical conductivity logging, using the direct-push technique, can provide a reliable and readily accomplished means of mapping subsurface unconsolidated geology.

\section{Acknowledgments}

The author gratefully acknowledges the City of McHenry, Illinois and, in particular, Mike Palmer, Water Superintendent, Department of Public Works. Without their overwhelming support of this project, including (1) access for installation of observation wells and collection of water-level and water-quality data from the observation wells, production wells and nearby streams and (2) sharing of well withdrawal records, this project could not have been completed.

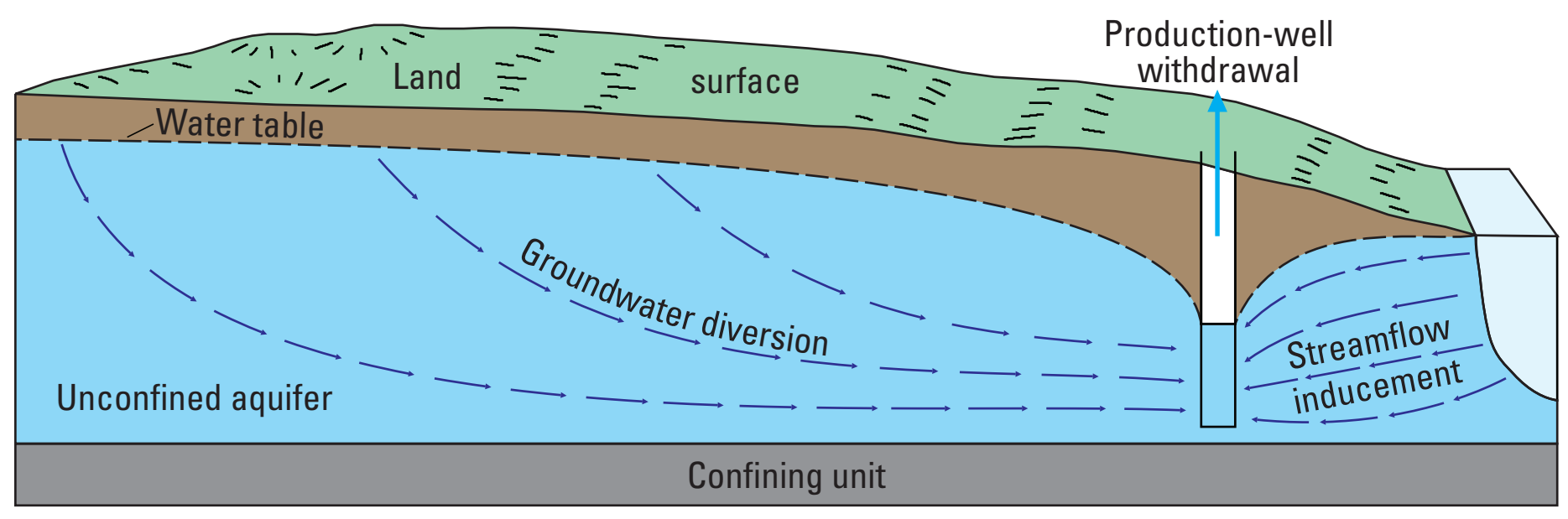

Potential effects of well withdrawals from a water-table aquifer that discharges to a stream. 
Laboratory analytical information for reported water-chemical data.

[ $\mu \mathrm{g} / \mathrm{L}$, microgram per liter; H, hydrogen; O, oxygen; B, boron; IP-AES, inductively coupled plasma-atomic emission spectrometry; MS, mass spectrometry; MS-NTI, negative thermal ionization mass spectrometry; na, not applicable]

\begin{tabular}{|c|c|c|c|c|}
\hline Constituent & CAS number & Parameter code & Analytical method & Reporting level, $\boldsymbol{\mu g} / \mathbf{L}$ \\
\hline Iron & $7439-89-6$ & 01046 & ICP-AES & 4 \\
\hline Boron & $7440-42-8$ & 01020 & ICP-AES & 2 \\
\hline $\mathrm{H}^{2} / \mathrm{H}^{1}$ & na & 82082 & MS & na \\
\hline $\mathrm{O}^{18} / \mathrm{O}^{16}$ & na & 82085 & MS & na \\
\hline $\mathrm{B}^{11} / \mathrm{B}^{10}$ & na & na & MS-NTI & na \\
\hline
\end{tabular}

\section{References}

Avery, C.F., 2005, Reversal of declining ground-water levels in the Chicago area: U.S. Geological Survey Fact Sheet FS-222-95, 2 p.

Balding, G.O., 1991, Changes in chloride concentration in water from municipal wells that tap aquifers in rocks of Cambrian and Ordovician age in northeastern Illinois, 1915-84: U.S. Geological Survey Water-Resources Investigations Report 90-4116, 52 p.

Bassett, R.L., Buszka, P.M., Davidson, G.R., and Chong-Diaz, Damaris, 1995, Identification of groundwater solute sources using boron isotope composition: Environmental Science \& Technology, v. 29, no. 12, p. 2915-2922.

Buszka, P.M., Fitzpatrick, John, Watson, L.R., and Kay, R.T., 2007, Evaluation of ground-water and boron sources by use of boron stable-isotope ratios, tritium, and selected waterchemistry constituents near Beverly Shores, northwestern Indiana, 2004: U.S. Geological Survey Scientific Investigation Report 2007-5166, 46 p.

Cunningham, W.L., and Schalk, C.W., comps., 2011, Groundwater technical procedures of the U.S. Geological Survey: U.S. Geological Survey Techniques and Methods 1-A1, 151 p. (available only online at http://pubs.usgs.gov/tm/lal/).

Dansgaard, W., 1964, Stable isotopes in precipitation: Tellus, v. 16 , no. 4 , p. $437-468$.

Feinstein, D.T., Fienen, M.N., Kennedy, J.L., Buchwald, C.A., and Greenwood, M.M., 2012, Development and application of a groundwater/surface-water flow model using MODFLOW-NWT for the Upper Fox River Basin, southeastern Wisconsin: U.S. Geological Survey Scientific Investigations Report 2012-5108, 124 p.

Franke, O.L., Reilly, T.E., Pollock, D.W., and LaBaugh, J.W., 1998, Estimating areas contributing recharge to wellsLessons from previous studies: U.S. Geological Survey Circular 1174, 14 p.
Gilkeson, R.H., Cartwright, Keros, Cowart, J.B., and Holtzman, R.B., 1983, Hydrogeologic and geochemical studies of selected natural radioisotopes and barium in groundwater in Illinois: Illinois State Geological Survey Contract/Grant Report 1983-6, 93 p.

Great Lakes Commission, 2003, The Great Lakes Basin Compact, accessed March 8, 2013, at http://www.glc.org/about/ glbc.html.

Heaton, T.H.E., 1986, Isotopic studies of nitrogen pollution in the hydrosphere and atmosphere-A review: Chemical Geology, v. 59, p. 87-102.

Hem, J.D., 1985, Study and interpretation of the chemical characteristics of natural water: U.S. Geological Survey WaterSupply Paper 2254, p. 161-162.

Illinois Environmental Protection Agency, 2013, unpublished Source Water Assessment Program (SWAP) ArcIMS Mapping Tool, accessed March 11, 2013, at password-secured http://maps.epa.state.il.us/website/swap/intro.htm.

Kay, R.T., 2013, Radium in groundwater from public-supply aquifers in northern Illinois, accessed October 21 11, 2013, at http://il.water.usgs.gov/proj/gwstudies/radium/.

Kay, R.T., Bayless, E.R., and Solak, R.A., 2002, Use of isotopes to identify sources of ground water, estimate ground-waterflow rates, and assess aquifer vulnerability in the Calumet region of northwestern Indiana and northeastern Illinois: U.S. Geological Survey Water-Resources Investigations Report 02-4213, p. 36-38.

Keys, W.S., 1990, Borehole geophysics applied to ground-water investigations: U.S. Geological Survey Techniques of WaterResources Investigations, book 2, chap. E-2, 150 p.

Lundquist, J.D., and Cayan, D.R., 2002, Seasonal and spatial patterns in diurnal cycles in streamflow in the western United States: Journal of Hydrometeorology, v. 3, p. 591-603. 
Meyer, S.C., Roadcap, G.S., Lin, Yu-Feng, and Walker, D.D., 2009, Kane County water resources investigations - Simulation of ground-water flow in Kane County and northeastern Illinois: Illinois State Water Survey Contract Report 2009-07, 425 p.

Meyer, S.C., Wehrmann, H.A., Knapp, H.V., Lin, Yu-Feng, Roadcap, G.S., Glatfelter, F.E., Angel, J.R., Thomason, J.R., and Injerd, D.A., 2012, Northeastern Illinois water supply planning investigations - Opportunities and challenges of meeting water demand in northeastern Illinois: Illinois State Water Survey Contract Report 2012-03, 221 p.

National Oceanic and Atmospheric Administration, 2011a, Climatological data Illinois, May 2011: National Climate Data Center, accessed October 25, 2013, at http://www1.ncdc. noaa.gov/pub/orders/IPS-C622813D-9CEB-4CCD-A7412726FC4A2F0B.pdf.

National Oceanic and Atmospheric Administration, 2011b, Climatological data Illinois, May 2011: National Climate Data Center, accessed October 25, 2013, at http://www1.ncdc. noaa.gov/pub/orders/IPS-4138C3C7-CD0A-454D-949A8630CD1928BE.pdf.

Perry, E.C., Jr., Grundl, T., and Gilkeson, R.H., 1982, H, O, and $\mathrm{S}$ isotopic study of the ground water in the Cambrian-Ordovician aquifer system of northern Illinois, in Perry, E.C., Jr., and Montgomery, C.W., eds., Isotope studies of hydrologic processes: DeKalb, Ill., Northern Illinois University Press, p. $35-45$.

Rosenberry, D.O., and LaBaugh J.W., 2008, Field techniques for estimating water fluxes between surface water and ground water: U.S. Geological Survey Techniques and Methods, book 4, chap. D2, 128 p.
Stonestrom, D.A., and Constantz, Jim, 2004, Using temperature to study stream-ground water exchanges: U.S. Geological Survey Fact Sheet 2004-3010, 4 p.

U.S. Census Bureau, 2013, Census 2010, accessed August 17, 2013, at http://www.census.gov/2010census/.

U.S. Geological Survey, variously dated, National field manual for the collection of water-quality data: U.S. Geological Survey Techniques of Water-Resources Investigations, book 9, chaps. A1-A9, variously paged (available online at http:// pubs.water.usgs.gov/twri9A).

U.S. Geological Survey, 2013, Fiber-optic distributed temperature sensing technology demonstration and evaluation project, accessed February 28, 2013, at http://water.usgs.gov/ ogw/bgas/fiber-optics/.

Visocky, A.P., Sherrill, M.G., and Cartwright, Keros, 1985, Geology, hydrology, and water quality of the Cambrian and Ordovician systems in northern Illinois: Illinois State Geological Survey Cooperative Groundwater Report 10, 136 p.

Winter, T.C., Harvey, J.W., Franke, O.L., and Alley, W.M., 1998, Ground water and surface water-A single resource: U.S. Geological Survey Circular 1139, 79 p.

Wisconsin Department of Natural Resources, 2013, Well inventory, drinking water data, accessed March 10, 2013, at http:// prodoasext.dnr.wi.gov/inter1/spinvent\$.startup.

For much of the data collected from these studies, refer to the U.S. Geological Survey National Water Information System (NWIS) Web site, http://waterdata.usgs.gov/nwis, and use the following NWIS site identifications for the local data-collection site names given in this report.

\begin{tabular}{|c|l|c|c|}
\hline $\begin{array}{c}\text { McHenry, Illinois, } \\
\text { site }\end{array}$ & \multicolumn{1}{|c|}{ NWIS site ID } & $\begin{array}{c}\text { Waukesha, } \\
\text { Wisconsin, site }\end{array}$ & NWIS site ID \\
\hline OB-1S & 422049088174401 & OW-11 & 425736088164601 \\
\hline OB-2S & 422049088174601 & OW-12 & 425739088164301 \\
\hline OB-2D & 422049088174603 & TW-11S & 425736088164401 \\
\hline OB-3S & 422047088174601 & FR-11 & 05543862 \\
\hline TW-3D & 422047088174602 & & \\
\hline MW-5 & 422048088174501 & & \\
\hline MW-6 & 422047088173801 & & \\
\hline S-IT & 05549070 & & \\
\hline S-2BC & 05549050 & & \\
\hline
\end{tabular}




\section{Conversion Factors}

Inch/Pound to SI

\begin{tabular}{lll}
\hline \multicolumn{1}{c}{ Multiply } & \multicolumn{1}{c}{ By } & \multicolumn{1}{c}{ To obtain } \\
\hline inch (in.) & \multicolumn{1}{c}{ Length } & \\
foot (ft) & 25.4 & millimeter $(\mathrm{mm})$ \\
mile (mi) & 0.3048 & meter $(\mathrm{m})$ \\
\hline \multicolumn{1}{c}{ Area } & kilometer $(\mathrm{km})$ \\
\hline acre & 1.609 & \\
square mile $\left(\mathrm{mi}^{2}\right)$ & 0.004047 & square kilometer $\left(\mathrm{km}^{2)}\right)$ \\
\hline & 2.590 & square kilometer $\left(\mathrm{km}^{2)}\right)$ \\
\hline foot per minute $(\mathrm{ft} / \mathrm{min})$ & \multicolumn{1}{c}{ Flow rate } & \\
cubic foot per second $(\mathrm{ft} / \mathrm{s})$ & 0.3048 & meter per minute $\left(\mathrm{m} / \mathrm{min}^{3}\right)$ \\
gallon per minute $(\mathrm{gal} / \mathrm{min})$ & 0.02832 & cubic meter per second $\left(\mathrm{m}^{3} / \mathrm{s}\right)$ \\
million gallons per day $(\mathrm{Mgal} / \mathrm{d})$ & 0.06309 & liter per second $(\mathrm{L} / \mathrm{s})$ \\
\hline
\end{tabular}

Temperature in degrees Celsius $\left({ }^{\circ} \mathrm{C}\right)$ may be converted to degrees Fahrenheit $\left({ }^{\circ} \mathrm{F}\right)$ as follows:

${ }^{\circ} \mathrm{F}=\left(1.8 x^{\circ} \mathrm{C}\right)+32$

Vertical coordinate information is referenced to the North American Vertical Datum of 1988 (NAVD 88).

Elevation, as used in this report, refers to distance above the vertical datum.

Electrical conductivity is given in milliSiemens per meter $(\mathrm{mS} / \mathrm{m})$.

Concentrations of chemical constituents in water are given either in milligrams per liter (mg/L) or micrograms per liter $(\mu \mathrm{g} / \mathrm{L})$.

$\delta$ (delta), as used in this report, refers to the stable isotope ratio $\delta x=[\mathrm{Rx} / \mathrm{RSTD})-1] \mathrm{x} 1,000$, where $\mathrm{Rx}$ and RSTD are the ${ }^{11} \mathrm{~B} /{ }^{10} \mathrm{~B},{ }^{2} \mathrm{H} /{ }^{1} \mathrm{H}$, and ${ }^{18} 0 /{ }^{16} \mathrm{O}$ values of the sample and reference standard. The value of $\delta$ is generally expressed in parts per thousand (\%o, or per mil).

Per mil, as used in this report, is equivalent to parts per thousand.

Distributed Temperature Sensing resolution is given in meters $(\mathrm{m})$, with 1 meter equivalent to about 3.28 feet.

For more information on the USGS — the Federal source for science about the Earth, its natural and living resources, natural hazards, and the environment, visit http://www.usgs.gov or call 1-888-ASK-USGS.

For an overview of USGS information products, including maps, imagery, and publications, visit http://www.usgs.gov/pubprod

To order this and other USGS information products, visit http://store.usgs.gov

Any use of trade, firm, or product names is for descriptive purposes only and does not imply endorsement by the U.S. Government. Although this information product, for the most part, is in the public domain, it also may contain copyrighted materials as noted in the text. Permission to reproduce copyrighted items must be secured from the copyright owner.

All photographs by Patrick Mills, U.S. Geological Survey, with the exception of figure 6B by Amy Gahala, U.S. Geological Survey.

\section{For more information on the described studies, please contact:}

Patrick Mills, author

U.S. Geological Survey

Illinois Water Science Center, Urbana

pcmills@usgs.gov
Daniel Feinstein

U.S. Geological Survey

Wisconsin Water Science Center, Middleton diffeinst@usgs.gov 